\title{
Molecular Materials for Organic Photovoltaics: Small is Beautiful
}

\author{
Jean Roncali,* Philippe Leriche, and Philippe Blanchard \\ Dedicated to Prof Francis Garnier on the occasion of his $75^{\text {th }}$ birthday
}

\begin{abstract}
An overview of some recent developments of the chemistry of molecular donor materials for organic photovoltaics (OPV) is presented. Although molecular materials have been used for the fabrication of OPV cells from the very beginning of the field, the design of molecular donors specifically designed for OPV is a relatively recent research area. In the past few years, molecular donors have been used in both vacuum-deposited and solutionprocessed OPV cells and both fields have witnessed impressive progress with power conversion efficiencies crossing the symbolic limit of $10 \%$. However, this progress has been achieved at the price of an increasing complexity of the chemistry of active materials and of the technology of device fabrication. This evolution probably inherent to the progress of research is difficult to reconcile with the necessity for OPV to demonstrate a decisive economic advantage over existing silicon technology. In this short review various classes of molecular donors are discussed with the aim of defining possible basic molecular structures that can combine structural simplicity, low molecular weight, synthetic accessibility, scalability and that can represent possible starting points for the development of simple and cost-effective OPV materials.
\end{abstract}

scalability of the synthesis of active OPV materials. In recent years, donor materials based on molecular chromophores have gained considerable interest in the various branches of research on OPV. In this context, the aim of this article is to discuss some recent developments of the chemistry of donor materials based on small molecular structures combining structural versatility, simplicity and low molecular weight, features that are generally associated with higher overall yield, lower environmental impact and easier up-scaling of the synthesis. It is hoped that emphasis on such structures will stimulate further synthetic chemistry oriented towards the reduction of the cost and environmental impact of active materials and thus contribute to a future industrial development of OPV. In order to clearly place the objectives of this short survey, special attention will be focused on donors with molecular weights $\leq 500$. After a brief survey intended to situate present OPV research in a historical perspective, the main classes of molecular structures

\section{Introduction}

The steady increase of energy demand associated with the emergence of environmental concerns has created a situation propitious to an intensification of research on the conversion of solar energy. In this context organic photovoltaics (OPV) is attracting increasing interest motivated in part by the lightness, plasticity, and flexibility of organic materials. However, the major reason to develop OPV is clearly an expected drastic reduction of the cost of PV electricity.

Although the active materials are of course key components of solar cells and represent a substantial part of the overall cost of the devices, a quasi exclusive focus and harsh competition aiming at the improvement of the power conversion efficiency $(P C E)$ of OPV cells has contributed to leave in the background the problems related to the cost, stability, environmental impact and

Dr J. Roncali, Prof. P. Leriche, Dr P. Blanchard Group Linear Conjugated Systems

CNRS MOLTECH-Anjou

University of Angers

2 Bd Lavoisier 49045, Angers, France

E-mail: jeanroncali@gmail.com

DOI: 10.1002/adma.201305999 that fulfil the above exposed conditions and with already established potential for PV conversion will be discussed with the aim of identifying possible directions for future research.

OPV cells are basically developed along two main lines. Thermal evaporation of active materials under vacuum was the initial method of fabrication. ${ }^{[1-10]}$ This technique presents several specific advantages such as possible use of insoluble materials often more stable than their soluble analogues, precise control of the thickness and deposition rate of the active layers and easy fabrication of multi-layered devices. The second simpler, cheaper and more recent approach involves the solution-processing of the active film. This method offers the possibility to work on large area of (eventually flexible) substrates by low energy-demanding technologies such as printing or roll-to-roll processes. As illustrated in this article, these two technologies developed in parallel have deeply influenced the chemistry of active OPV materials.

Since the pioneering work of the seventies and until recently vacuum-deposited cells have been based on dyes and pigments like e.g., phthalocyanines, squaraines or merocyanines initially developed for other applications such as tainting, paint or xerography. ${ }^{[1-7]}$ Although the enhancement of the photo-generation of charges in a phthalocyanine in the presence of an electron-acceptor had been reported in $1980,,^{[2]}$ the fabrication of 
the first donor-acceptor (D/A) heterojunction by Tang in $1986^{[8]}$ is generally considered as the beginning of the "modern era" of OPV. However, research carried out in the next few years basically involved the same molecular donors..$^{[9,10]}$

Conjugated polymers (CPs), widely investigated since the end of the seventies, form the second big class of donors for OPV ${ }^{[11]}$ The fabrication of the first organic light-emitting diodes (OLED) based on CPs in 1990 has generated a considerable interest for the semiconducting properties of these materials. ${ }^{[12]}$ However, it took a few more years before CPs entered the field of OPV. A first example of solar cell based on poly(thiophene) was reported in 1984 by Garnier et al., ${ }^{[13]}$ but the real debut of CP-based OPV started ca. ten years later triggered by two simultaneous discoveries. The first is the demonstration of photo-induced electron transfer between CPs and fullerene $\mathrm{C}_{60}$ by Sariciftci et al. ${ }^{[14]}$ and the second is the invention of the concept of bulk heterojunction $(\mathrm{BHJ})$ solar cells. ${ }^{[15,16]}$ In $\mathrm{BHJ}$ cells the huge extension of the area of the heterojunction interface resulting from the formation of interpenetrated networks of D and A materials allows to circumvent a major limitation of planar heterojunctions $(\mathrm{PHJ})$ related to the short exciton diffusion-length in organic materials. The first $\mathrm{BHJ}$ cells were based on soluble derivatives of poly(p-phenylenevinylene) (PPV). ${ }^{[15,16]}$ The initial values of $P C E$ of $\sim 1.0 \%$ raised rapidly to $2.50 \%,{ }^{[17]}$ while some time later PPVs were supplanted by poly(3-hexylthiophene) $(\mathrm{P} 3 \mathrm{HT})^{[18]}$ which became the new standard material and led, after intensive of optimization, to PCE of $4.5-5.0 \%$ in $2005 .{ }^{[19,20]}$

Although low band gap CPs have been investigated for a long time, ${ }^{[21]}$ the synthesis of the first low band gap CPs specifically designed for OPV started at the turn of the millenium, ${ }^{[22,23]}$ and it was only in 2008 that low band gap polymers capable of surpassing P3HT were synthesized. ${ }^{[24]}$ In the past five years new classes of low band gap polymers have generated impressive progress and recently PCE of $\sim 9.0 \%$ have been reported for single junction BHJ cells. ${ }^{[25,26]}$

In spite of these remarkable results, CPs pose some problems related to the reproducibility of their synthesis, purification, and hence electronic properties. In fact the crude materials contain conjugated chains of various lengths and require fractioning with different solvents in order to reduce polydispersity. Furthermore, it is often necessary to remove remnant terminal groups by appropriate chemical treatment. These additional processes contribute to increase the cost and environmental impact of the material.

A possible alternative consists in the replacement of CPs by soluble molecular donors. Besides reproducible synthesis and purification, molecules allow more direct and reliable analyses of structure-properties relationships. Initiated in $2005,{ }^{[27]}$ this research area has rapidly grown and led to the synthesis of many classes of chromophores ${ }^{[28]}$ such as 3D oligothiophenes ${ }^{[29]}$ triphenylamines, ${ }^{[30]}(\mathbf{1})$, diketopyrrolopyrroles (2), ${ }^{[31]}$ borondipyrromethenes (3), ${ }^{[32]}$ indigos (4), ${ }^{[33]}$ dicyanopyrane derivatives (5), ${ }^{[34]}$ (Figure 1) and many other tailored $\pi$-conjugated molecules. ${ }^{[28]}$ The field has progressed rapidly and several groups recently reported PCE of $\sim 8.0 \%$ comparable to those obtained with the best polymers. ${ }^{[35-37]}$ Thus, Bazan et al. have synthesized hybrid D-A-D-A-D oligothiophenes containing two benzothiadiazole groups (6). ${ }^{[35]}$ Chen et al. have developed A-D-A oligothiophenes with different rigid median blocks like e.g., dithienobenzene $(7)^{[36]}$ while Li et al.

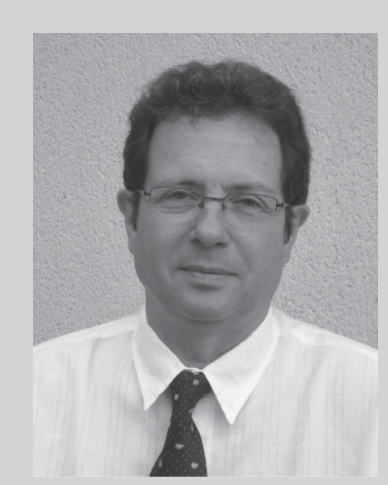

Jean Roncali received his Ph.D. in 1984 in Paris under the supervision of Francis Garnier. After successive positions as engineer and researcher in the Laboratory of Molecular Materials of CNRS, in 1991 he moved to the University of Angers to create the Linear Conjugated Systems Group as Research Director. Among others, Jean Roncali has received the Grammatikakis-Neuman Prize of the French Academy of Sciences in 2002 and the Pierre Süe Great Prize of the French Chemical Society in 2008. $\mathrm{His}$ research deals with the design of tailored functional $\pi$-conjugated systems for applications in electrode materials photonics, molecular electronics, energy conversion and storage, and organic photovoltaics.

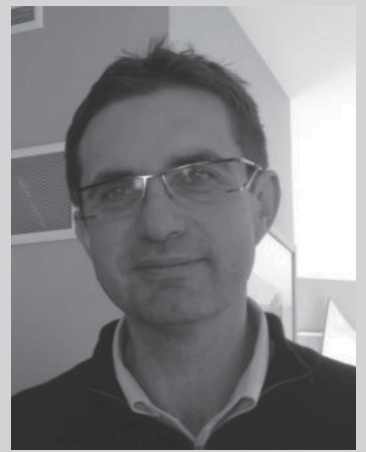

Philippe Leriche was born in Bretagne and studied chemistry in Rennes and Nantes. After a PhD in organic chemistry under the supervision of Pr Gorgues (Angers, France) and Becher (Odense, Denmark) in 1996, he was a postdoctoral fellow with $\mathrm{Pr}$ Cava (Tuscaloosa, USA) and became assistant professor (1998) and professor (2009). He was head of chemistry department from 2009 to 2012 when he became assistant director of the Faculty of Sciences of Angers). His main research interests cover design, synthesis, and characterization of molecular materials for organic electronics and photonics.

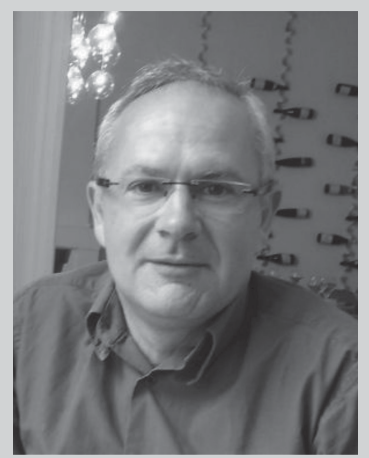

After a Ph.D. thesis on TTFbased molecular materials in 1994 under the supervision of Professors G. Duguay (Nantes) and A. Gorgues (Angers), a postdoctoral fellowship on electroactive TTF-based macrocycles in the group of ). Becher (Odense, Denmark), P. Blanchard joined the group of J. Roncali as CNRS Researcher in 1995. He became CNRS Research Director in 2007. His current interests concern the design, synthesis and characterization of pi-conjugated systems for molecular and organic electronics. 


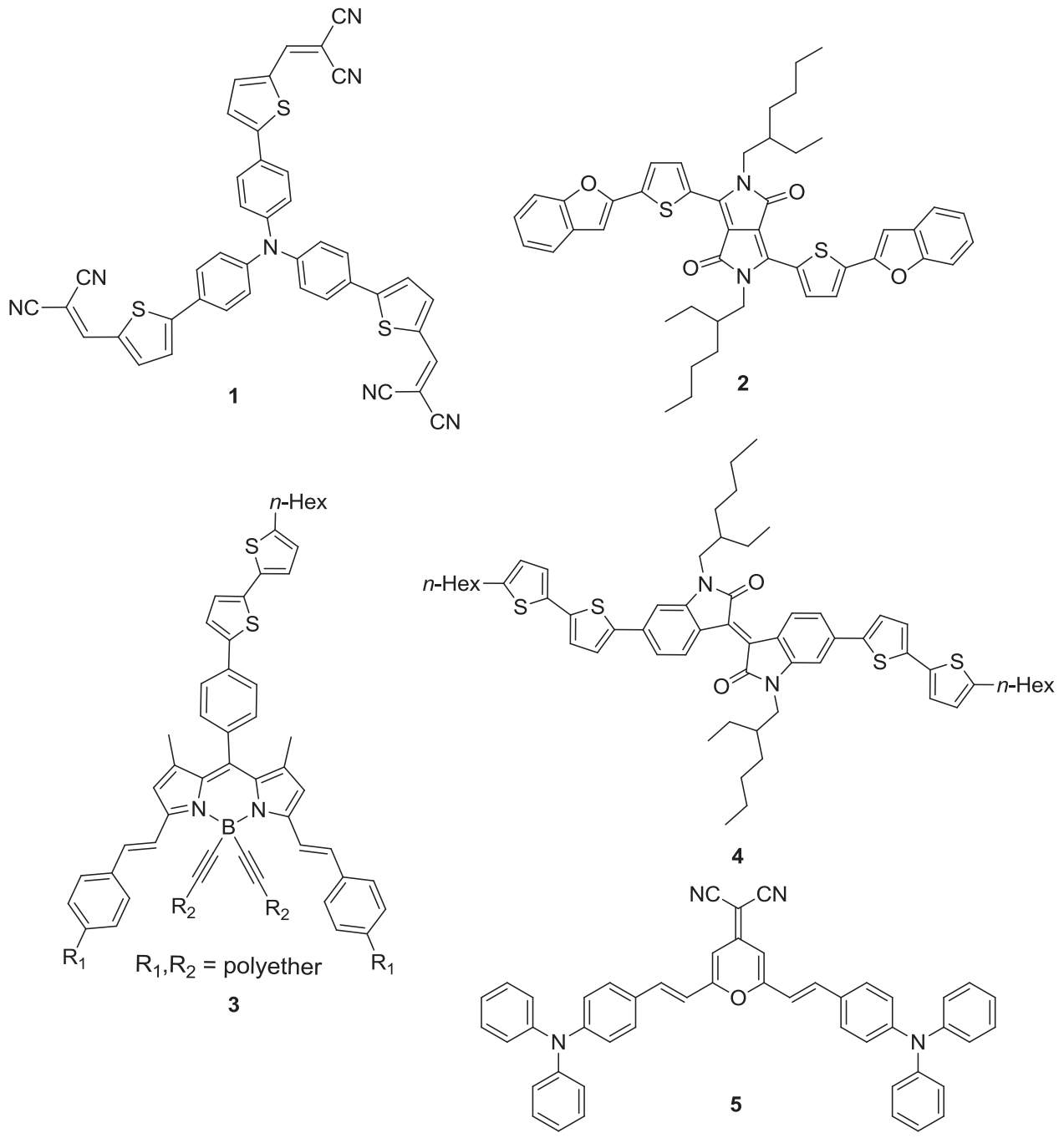

Figure 1. Chemical structures of compounds 1-5.

used the same median unit to create a 2D conjugated system (8) (Figure 2) and obtained high PCE without resorting to additives, in contrast to the two previous record examples. ${ }^{[3]}$ Vacuumdeposited OPV has also witnessed rapid progress and recently the groups of Wong ${ }^{[38]}$ and Bäuerle ${ }^{[39]}$ reported stack multi-layer devices with PCE of $6.80-6.90 \%$. However, donors for vacuumdeposited cells have generated less effort in synthetic chemistry than soluble molecules while advances in the technology of multilayer cells have strongly contributed to the progress of the field.

During a period of intensive research focused on the synthesis of new materials, the cost of the target compounds is generally not taken into consideration. However, now that the symbolic limit of $10 \% P C E^{[40]}$ has clearly demonstrated the scientific credibility of OPV, questions such as cost, environmental impact and scalability of the synthesis of active materials will play a key role in the industrial destiny of OPV. Although it is widely accepted that the major motivation for developing OPV is an expected drastic reduction of the cost of PV electricity compared to silicon technology, the progress accomplished in recent years has involved a considerable complication of the structure, synthesis and processing of active materials and of the architecture and fabrication of OPV cells. In this context it could be interesting and timely to reconsider the problem of the synthesis of OPV materials from a different viewpoint taking into account the criteria required by a possible industrial development. ${ }^{[41,42]}$

\section{Molecular Donors Based on Low Molecular Weight Chromophores}

\subsection{Oligothiophenes}

Oligothiophenes (nTs) form an important class of organic semiconductors widely used for the realization of OFETs. Already in 1974, Khun et al. published a first study of the photoelectrical behavior of a monolayer of quinquethiophene (9) (Figure 4) sandwiched between a semi-transparent aluminium layer and a mercury drop and measured the photo-current as a function of applied bias voltage. ${ }^{[43]} \mathrm{A}$ first prototype of bilayer D/A heterojunction cell was reported in 1995 by Shirota et al. who used 


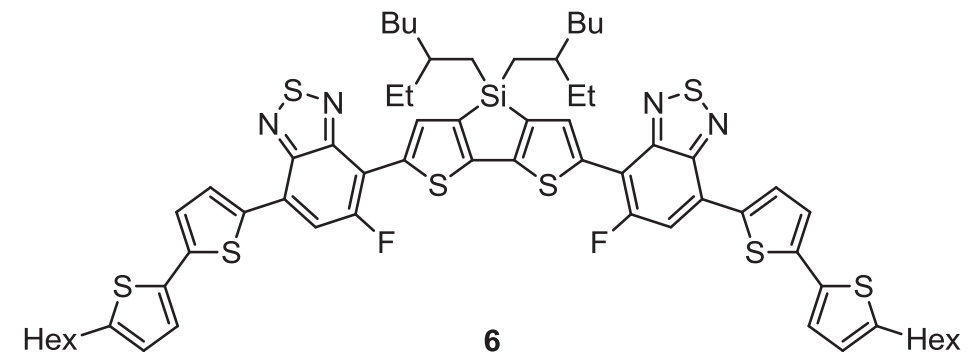<smiles></smiles>

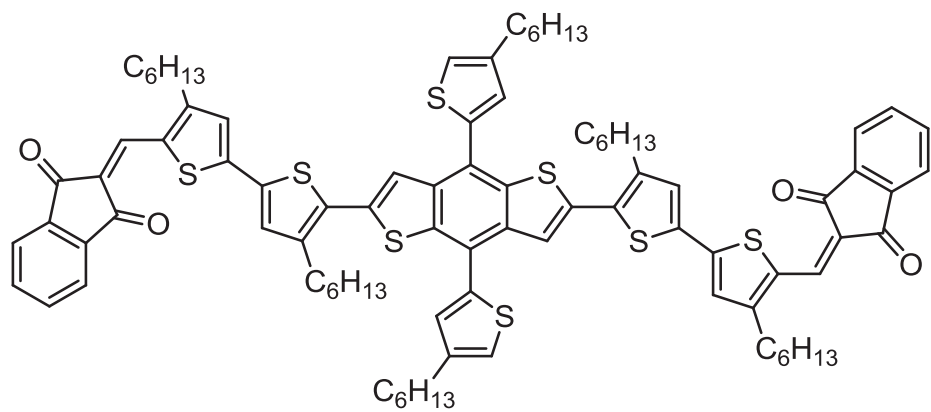

8

Figure 2. Chemical structures of compounds 6-8.

vacuum deposited octithiophene (11) as donor and a perylenebased pigment as acceptor. Under white light illumination at $105 \mathrm{~mW} \mathrm{~cm}^{-2}$ the cell delivered a short-circuit current density $\left(U_{\text {sc }}\right)$ of $2.90 \mathrm{~mA} \mathrm{~cm}^{-2}$, an open circuit voltage $\left(V_{\text {oc }}\right)$ of $0.42 \mathrm{~V}$ and a fill-factor $(F F)$ of 0.50 leading to a conversion efficiency of $0.59 \% .{ }^{[44]}$ Videlot et al. have fabricated Schottky diodes based on thin films of 11 and analyzed the effect of the orientation of molecules on the substrate on the performances of the cells. The horizontal orientation was obtained by a rubbing technique. A blue shift of $\lambda_{\max }$ was observed for the vertically oriented molecules. No PV effect was observed in this case while a small $P C E$ was observed for the horizontally oriented molecules. ${ }^{[45]}$

More recently, Sakai et al. have reported a first example of hybrid heterojunction cell (HHJ) based on sexithiophene 10. ${ }^{[46]}$ $\mathrm{HHJ}$ cells involves a co-evaporated layer of donor and acceptor sandwiched between layers or pure donor and acceptor. A PHJ bilayer cell $10 / \mathrm{C}_{60}$ gave a $P C E$ of $0.75 \%$ and rather low $V_{\text {oc }}$ of $0.35 \mathrm{~V}$. Then by optimizing the $10 / \mathrm{C}_{60}$ ratio in a $\mathrm{HHJ}$ device a $P C E$ of $1.50 \%$ was obtained for a $4 \mathrm{~mm}^{2}$ multi-layer device involving BCP (Figure 3) as exciton blocking layer.

Oligothiophene-S-S dioxides have been extensively investigated as emitters for OLEDs by the group of Barbarella. ${ }^{[4]}$
Conversion of one or more thiophene rings into the corresponding $S$-S dioxides leads at the same time to an enhanced $\pi$-electron delocalization due to the de-aromatization of the ring and to a strong increase of electron affinity. On this basis, Camaioni et al. have reported one of the first studies of the effect of structural modification on the PV properties of nTs. S-S dioxides $(12,13)$ (Figure 4) were used as electron acceptor material in $\mathrm{BHJ}$ cells with P3HT as donor. While the overall PCE of the devices remained low, a net effect of the presence of the acceptor was demonstrated compared to a device based on pure P3HT, with in particular an increase of $V_{\text {oc }}$ from $0.40 \mathrm{~V}$ to ca. $1.0 \mathrm{~V}$. While precise structure-properties relationships were difficult to establish, the largest effects on $V_{\text {oc }}$ were observed with compounds possessing an internal $S, S$ dioxide group such as (13). ${ }^{[48]}$

Intriguing results have been published in 2006 by Liu et al. who synthesized quater- and quinque-thiophene with a terminal vinyl group and used them as donor in bilayer cells with perylenetetracarboxilic dianhydride (PTCD) as acceptor. The devices gave moderate $J_{\mathrm{sc}}$ of 1.98 and $1.92 \mathrm{~mA} \mathrm{~cm}{ }^{-2}$ for 14 and 15 respectively and PCE of 2.30 and $2.67 \%$. Unusually high $V_{\mathrm{oc}}$ of 2.07 and $1.87 \mathrm{~V}$ were reported for cells based on 14 and 15 while a control experiment with unsubstituted $4 \mathrm{~T}$ gave 


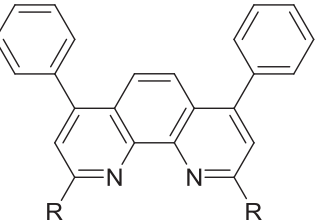

BPhen $\mathbf{R}=\mathbf{H}$

$B C P R=M e$

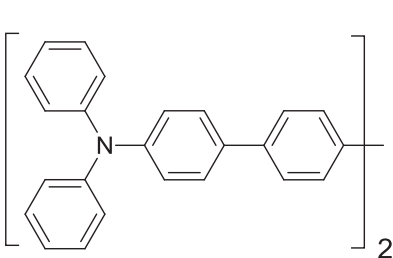

4P-TPD<smiles>CC(C)[Pb](Br)(Br)c1ccccc1-c1ccc(N(c2ccc(-c3ccccc3)cc2)c2ccc(C3(c4ccc(N(c5ccc(-c6ccccc6)cc5)c5ccc(-c6ccccc6)cc5)cc4)c4ccccc4-c4ccccc43)cc2)cc1</smiles>

BPAPF<smiles>Nc1ccc(N(c2ccccc2)c2ccc3ccccc3c2)cc1</smiles>

TNTATA<smiles>N#CC(C#N)=c1c(F)c(F)c(=C(C#N)C#N)c(F)c1F</smiles>

F4-TCNQ
MeOTPD

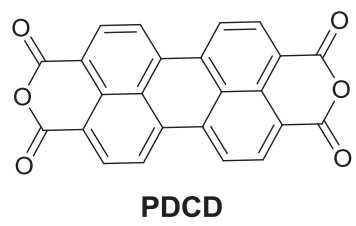

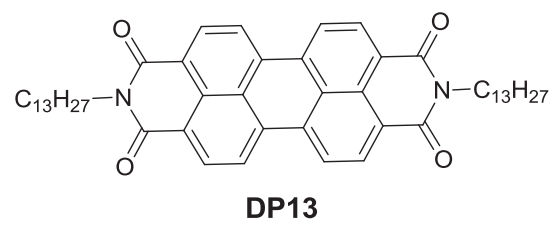

Figure 3. Auxilliary compounds for OPV cells.

a $V_{\text {oc }}$ of $0.90 \mathrm{~V} .^{[49 \mathrm{a}]}$ Until now these experiments have not been reproduced nor contradicted by other groups but if confirmed these results would certainly open interesting new directions for the molecular design of donors for OPV. The same group has reported PHJ cells based on vacuum deposited cyano-substituted ter- and quaterthiophenes $(\mathbf{1 6}, \mathbf{1 7})$ (Figure 4) and PTCD. ${ }^{[49 \mathrm{~b}]}$ Simple devices ITO/16 or 17/PCDT/Al of unspecified active area gave $J_{\mathrm{sc}}$ of 7.60 and $9.68 \mathrm{~mA} \mathrm{~cm}^{-2}$ for 16 and 17 respectively with $V_{\text {oc }}$ of 0.65 and $0.83 \mathrm{~V}$ and PCE of 1.51 and $2.10 \%$. However, the cells show poor FF values (24 and 20\%), suggesting much room for improvement. The rather large values of $J_{\text {sc }}$ could benefit form the large absorption of the PTCD acceptor in the 400-600 $\mathrm{nm}$ region namely beyond that of the donors. ${ }^{[49 \mathrm{~b}]}$

Another example of modification of nTs in view of PV conversion was reported by Yassar et al. who synthesized a 4T with a terminal dicyanovinyl group (18) (Figure 5). A large bathochromic shift of the absorption onset was observed compared to unsubstituted 4T, however the Schottky diode fabricated by sandwiching the vacuum-deposited molecule between ITO and aluminium electrodes delivered only a low $J_{\mathrm{sc}} \cdot{ }^{[50]}$

Bäuerle et al. have extended the use of the dicyanovinyl end-group to a large library of nTs (19-21)..$^{[51-58]}$ In collaboration with the group of Leo they have investigated the PV properties of these molecules in sophisticated vacuum-deposited multi-layer devices involving optimized hole and electron transporting layers. In a first paper, a $5 \mathrm{~T}$ with four butyl groups (20c) was used as donor with $\mathrm{C}_{60}$ as electron acceptor. Two different multi-layer devices were fabricated involving ITO/ $\mathrm{Au} /$ hole-transporting layer (HTL)/Donor/C $60 / \mathrm{BPhen} / \mathrm{Al}$. Two types of HTL combinations were used namely p-doped MeoTPD/4P-TPD in the first case and p-doped Di-NPB/Di-NPB in the second type of device. The dopant was either F4-TCNQ or a proprietary material. Cells of 3-4 $\mathrm{mm}^{2}$ active area gave high $J_{\mathrm{sc}}$ values $\sim 12 \mathrm{~mA} \mathrm{~cm}^{-2}$ and PCE of 2.00 and $2.20 \%$ however, the FF values remained low despite the presence of the doped HTL system. The increase of the doping level of the HTL significantly improved the FF raising PCE up to $3.40 \% .{ }^{[51]}$ Replacement of the four butyl substituents $R_{2}$ by four ethyl groups (20b) reduces PCE values to 1.20 and $2.50 \%$ (depending on the HTL system) due in particular to a lower FF despite the fact that 20b presents a hole mobility ca. three times higher than 20c. ${ }^{[52]}$

A crystallographic study of $4 \mathrm{Ts}$ 19a-c has revealed the key role of the length of the alkyl substituent $\mathrm{R}$ on the molecular packing and on the PV performances of the resulting cells. Multi-layer $\mathrm{HHJ}$ cells with a co-evaporated donor: $\mathrm{C}_{60}$ active layer showed that the best results were obtained with $19 \mathrm{~b}(\mathrm{R}=$ $\mathrm{Me}$ ) with a $J_{\mathrm{sc}}$ of $6.50 \mathrm{~mA} \mathrm{~cm}{ }^{-2}$ and a PCE of $3.80 \% .{ }^{[53]}$ 
9<smiles>c1csc(-c2ccc(-c3ccc(-c4ccc(-c5cccs5)s4)s3)s2)c1</smiles>

10<smiles>c1csc(-c2ccc(-c3ccc(-c4ccc(-c5ccc(-c6cccs6)s5)s4)s3)s2)c1</smiles>

11<smiles>c1csc(-c2ccc(-c3ccc(-c4ccc(-c5ccc(-c6ccc(-c7ccc(-c8cccs8)s7)s6)s5)s4)s3)s2)c1</smiles>

12<smiles>[R5][SiH2]C1=CC=C(c2ccc(-c3ccc(-c4ccc(C5=CC=C([SH][R3])S5(=O)=O)s4)s3)s2)S1(=O)=O</smiles>

13

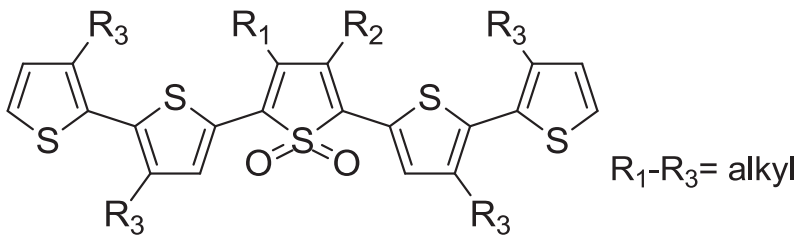

14<smiles>C=Cc1ccc(-c2ccc(-c3ccc(-c4cccs4)s3)s2)s1</smiles>

15<smiles>C=Cc1ccc(-c2ccc(-c3ccc(-c4ccc(-c5cccs5)s4)s3)s2)s1</smiles>

16<smiles>N#Cc1ccc(-c2ccc(-c3cccs3)s2)s1</smiles>

17<smiles>N#Cc1ccc(-c2ccc(-c3ccc(-c4cccs4)s3)s2)s1</smiles>

Figure 4. Chemical structures of compounds 9-17.

A 6T bearing four butyl substituents (21c) has been used in a large series of multi-layer $\mathrm{PHJ}, \mathrm{BHJ}$ or $\mathrm{HHJ}$ cells. The highest $V_{\mathrm{oc}}(0.90 \mathrm{~V})$ was obtained with a $\mathrm{PHJ}$ cell and the largest $J_{\mathrm{sc}}$ $\left(8.20 \mathrm{~mA} \mathrm{~cm}{ }^{-2}\right.$ ) with a HHJ. However, the best cells of both types gave comparable PCE of 3.00-3.10\%. ${ }^{[54]}$ The effect of the substrate temperature during vacuum deposition has been analyzed on a $6.3 \mathrm{~mm}^{2}$ six-layer $\mathrm{HHJ}$ based on a $6 \mathrm{~T}$ with four ethyl side groups (21b). Heating the substrate during deposition of the mixed layer increased $J_{\mathrm{sc}}$ from 4.10 to $6.50 \mathrm{~mA} \mathrm{~cm}^{-2}$ and
PCE of from 1.60 to $3.80 \% .{ }^{[55]}$ On the other hand a HHJ cell based on sexithiophene 21d with butyl substituents reached a PCE of $4.90 \%\left(J_{\mathrm{sc}} \sim 10.9-11.60 \mathrm{~mA} \mathrm{~cm}^{-2}\right)$ when the mixed layer was deposited on a heated substrate. ${ }^{[56]}$ The effect of the length of the conjugated system has been analyzed on a series of nTs containing 3 to 6 thiophene rings. As expected, chain extension produces a red shift of $\lambda_{\max }$ and an increase of the HOMO level. ${ }^{[57]} \mathrm{PHJ}$ cells of ca. $3 \mathrm{~mm}^{2}\left(\mathrm{C}_{60} /\right.$ donor/ $\mathrm{BPAPF} / \mathrm{p}$-doped BPAPF/NDP9/Au) (were NDP9 is a proprietary dopant) fabricated with 4T (19a), 5T (20a) and 6T (21a) gave $J_{\mathrm{sc}}$ of $2.90,5.10$ and $4.80 \mathrm{~mA} \mathrm{~cm} \mathrm{~cm}^{-2}$ and PCE of $1.20,2.50$ and $2.80 \%$. Seven-layer $\mathrm{HHJ}$ cells of $5 \mathrm{~mm}^{2}$ were realized with a mixed active layer $20 \mathrm{a}: \mathrm{C}_{60}$ of variable thickness. The best cell gave a $J_{\mathrm{sc}}$ of $11.10 \mathrm{~mA} \mathrm{~cm} \mathrm{~cm}^{-2}$, a $V_{\text {oc }}$ of $0.97 \mathrm{~V}$ and a PCE of $5.20 \%$ i.e. twice larger than that obtained with the PHJ based on the same donor. ${ }^{[57]}$

The same group has recently investigated the PV performances of three 5Ts with methyl groups at various positions of the conjugated chain (20e-g). Again crystallographic studies have confirmed the strong influence of the number and position of the substituents on the molecular packing. The PV performances were analyzed on $\mathrm{HHJ}$ stack cells of $6.6 \mathrm{~mm}^{2} \quad\left(\mathrm{ITO} / \mathrm{C}_{60} /\right.$ donor: $\mathrm{C}_{60} / \mathrm{BPAF} /$ doped BPAF:NDP9/NDP9/Au). Compounds 20e and $20 \mathrm{f}$ gave comparable results with $J_{\mathrm{sc}}=$ $9.50 \mathrm{~mA} \mathrm{~cm}^{-2}$ and $P C E=4.80 \%$ while donor $20 \mathrm{~g}$ gave better results with $J_{\mathrm{sc}}=11.10 \mathrm{~mA}$ $\mathrm{cm}^{-2}$ and $P C E=6.10 \%$. A further device optimization by introduction of an additional layer of $\mathrm{n}$-doped $\mathrm{C}_{60}$ between ITO and the pure $\mathrm{C}_{60}$ layer gave a maximum $J_{\mathrm{sc}}=11.50 \mathrm{~mA} \mathrm{~cm}-2$ and PCE of $6.90 \% .{ }^{[39]}$

In order to increase the $V_{\text {oc }}$ of OPV cells Bäuerle et al. synthesized a series of fivering systems combining the benzothiadiazole (BzT) acceptor group and thiophene units with two trifluoroacetyl end groups (22) (Figure 5). Compounds 22a and 22b absorb at 509 and $518 \mathrm{~nm}$ respectively, values similar to those of compounds 20 while the $\lambda_{\max }$ of compound $22 \mathrm{c}$ is hypsochromically shifted to 466 due to steric hindrance to planarity. Compounds 22a and 22b were used as donor in PHJ cells of $2.76 \mathrm{~mm}^{2}$ (ITO/C 60 /Donor/BPAF/BPAF:NDP9/p$\mathrm{ZnPc} / \mathrm{Au})$. High $V_{\text {oc }}$ of 1.10 and $1.17 \mathrm{~V}$ were obtained for respectively $22 \mathrm{a}$ and $22 \mathrm{~b}$ with $J_{\mathrm{sc}}$ of 4.38 and $4.04 \mathrm{~mA} \mathrm{~cm}^{-2}$ and PCE of 1.45 and $1.56 \% .{ }^{[58]}$ Five-ring systems with two BzT end groups have been synthesized by the same group (23a, b). These compounds absorb at shorter wavelengths that the previous ones and show lower molecular absorption coefficients (ca. $30000 \mathrm{M}^{-1} \mathrm{~cm}^{-1}$ vs $50000 \mathrm{M}^{-1} \mathrm{~cm}^{-1}$ for compounds 22). 
18<smiles>N#CC(C#N)=Cc1ccc(-c2ccc(-c3ccc(-c4cccs4)s3)s2)s1</smiles>

19<smiles>[R]c1c(C=C(C#N)C#N)sc(-c2ccc(-c3ccc(-c4sc(C=C(C#N)C#N)c([R])c4[R])s3)s2)c1[R]</smiles>

$$
\begin{aligned}
& \text { a } R=H \\
& \text { b } R=M e \\
& \text { c } R=E t
\end{aligned}
$$

20<smiles>[R]c1c(C=C(C#N)C#N)sc(-c2sc(-c3sc(-c4sc(-c5sc(C=C(C#N)C#N)c([R])c5[R])c([R])c4[R])c([R])c3[R])c([R])c2[R])c1[R]</smiles>

a $\mathrm{R}_{1}=\mathrm{R}_{2}=\mathrm{R}_{3}=\mathrm{H}$

b $\mathrm{R}_{1}=\mathrm{R}_{3}=\mathrm{H}, \mathrm{R}_{2}=\mathrm{Et}$

c $\mathrm{R}_{1}=\mathrm{R}_{3}=\mathrm{H}, \mathrm{R}_{2}=n-\mathrm{Bu}$

d $\mathrm{R}_{1}=\mathrm{R}_{3}=\mathrm{H}, \mathrm{R}_{2}=n-\mathrm{Bu}$

e $R_{1}=M e, R_{2}=R_{3}=H$

f $R_{1}=R_{3}=H, R_{2}=M e$

g $R_{1}=R_{2}=H, R_{3}=M e$

21<smiles>[R]c1cc(C=C(C#N)C#N)sc1-c1sc(-c2ccc(-c3ccc(-c4sc(-c5sc(C=C(C#N)C#N)cc5[R])c([R])c4[R1])s3)s2)c([R3])c1[R]</smiles>
a $R_{1}=R_{2}=R_{3}=H$
b $R_{1}=H, R_{2}=R_{3}=E t$
c $\mathrm{R}_{1}=\mathrm{H}, \mathrm{R}_{2}=\mathrm{R}_{3}=n-\mathrm{Bu}$
d $\mathrm{R}_{1}=\mathrm{R}_{3}=n-\mathrm{Bu}, \mathrm{R}_{2}=\mathrm{H}$

22<smiles>[R]c1c(-c2ccc(C(=O)OC(F)(F)F)s2)sc(-c2ccc(-c3sc(-c4ccc(C(=O)OC(F)(F)F)s4)c([R2])c3[R2])c3nsnc23)c1[R2]</smiles>

$$
\begin{aligned}
& \text { a } \mathrm{R}_{1}=\mathrm{R}_{2}=\mathrm{H} \\
& \text { b } \mathrm{R}_{1}=n-\mathrm{Bu}, \mathrm{R}_{2}=\mathrm{H} \\
& \text { c } \mathrm{R}_{1}=\mathrm{R}_{2}=\mathrm{Et}
\end{aligned}
$$

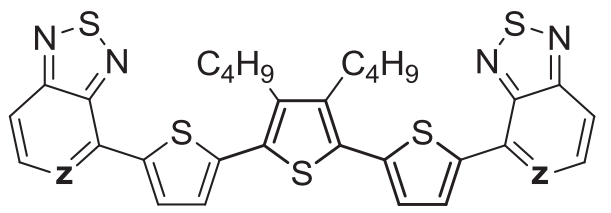

Figure 5. Chemical structures of compounds 18-23.

These two molecules were used as donor in both $\mathrm{PHJ}$ and BHJ multi-layer cells of $2.76 \mathrm{~mm}^{2} \mathrm{PHJ}$ : (ITO/C 60 /donor/ Di-NPB/Di-NPB p-doped with NDP9/NDP9/Au); BHJ (ITO/ $\mathrm{C}_{60} /$ donor/donor: $\mathrm{C}_{60} / \mathrm{BPAF} / \mathrm{BPAF}$-doped with NPD9/NPD9/ $\mathrm{Au})$. Cells based on compound 23a gave PCE of 1.73 and $1.50 \%$ with $J_{\mathrm{sc}}<3.0 \mathrm{~mA} \mathrm{~cm}{ }^{-2}$, the PHJ cell being the most efficient. Replacement of the phenyl ring by pyridyl in 23b produces a small increase of $V_{\text {oc }}$ from $0.98 \mathrm{~V}$ to 1.00 and $1.05 \mathrm{~V}$ for the $\mathrm{PHJ}$ and $\mathrm{BHJ}$ respectively with $P C E$ of $3.10 \%$ for the $\mathrm{PHJ}$ and $1.94 \%$ for BHJ. The much lower PCE observed in BHJ cell was not clearly understood. ${ }^{[59]}$

\subsection{EDOT-Based Systems}

3,4-ethylenedioxythiophene (EDOT) is an important and versatile building block widely used for the synthesis of functional $\pi$-conjugated systems. ${ }^{[60]}$ However, EDOT has been seldom used for the design of active OPV materials. In fact the strong donor effect of EDOT leads to a large increase of the HOMO level of the system in which it is incorporated which results in a dramatic decrease of $V_{o c}{ }^{[61]} \mathrm{A}$ first attempt to test the possible use of EDOT in OPV materials has involved the analysis of the structure-properties relationships of three short-chain model 
compounds used as donor in basic bilayer cells fabricated by thermal evaporation of 24-26 (20 nm) and Bis- $N, N^{\prime}$-bis-tridecylperylenediimide (DP13) as acceptor sandwiched between ITO and aluminium electrodes (Figure 6). The pure 3T compound 24 gave a $J_{\text {sc }}$ of $140 \mu \mathrm{A} \mathrm{cm} \mathrm{cm}^{-2}$, a $V_{\text {oc }}$ of $0.76 \mathrm{~V}$ and a $F F$ of 0.32 leading to a PCE of $0.042 \%$. The introduction of two EDOT units produces a dramatic decrease of $J_{\mathrm{sc}}$ and $F F$ while for the three EDOT molecule 26, $J_{\mathrm{sc}}$ increases to $160 \mu \mathrm{A} \mathrm{cm} \mathrm{cm}^{-2}$ and FF to $42 \%$ while $V_{\text {oc }}$ drops from 0.76 to $0.32 \mathrm{~V}$ leading to a decrease of $P C E$ to $0.030 \%$. ${ }^{[27]}$ These first results suggested that EDOT can contribute to improve the hole-transport properties of the donor but should be used with care due to the large increase of the HOMO of the molecule. ${ }^{[61]}$ A particularly difficult problem is that the EDOT group can strongly modify intermolecular interactions in a way difficult to predict. Thus, the characterization of simple bilayer cells realized by vacuum deposition of mixed oligomers 27 and 28 and DP13 as acceptor showed that, although as expected low $V_{\text {oc }}$ are observed in both cases $(0.16$ and $0.28 \mathrm{~V}) J_{\mathrm{sc}}$ is more than ten times larger with compound 28 (332 vs $30 \mu \mathrm{A} \mathrm{cm} \mathrm{cm}^{-2}$ ). The comparison of the UV-Vis absorption spectra of the two compounds in solution and in the solid state reveals two drastically different behaviors namely a broadening of the spectrum with a red shift of $\lambda_{\max }$ for 28 and a $60 \mathrm{~nm}$ blue shift of $\lambda_{\max }$ with sharpening of the absorption band for 27. These contrasting behaviors reveal quite different molecular interactions in the solid-state and suggest the formation of $H$-aggregate in the case of 27 and J-aggregates for 28. ${ }^{27]}$

The use of the EDOT block in donor materials was recently revisited with the synthesis of a series of trimers with terminal dicyanovinyl group (29-31). ${ }^{[62]}$ The idea was to take advantage of the strong donor properties of EDOT to reduce the size of oligothiophene donors. As expected the grafting of the dicyanovinyl group leads to an internal charge transfer that produces a large red shift of the $\lambda_{\max }$ of the molecule. Furthermore $\lambda_{\max }$ shifts bathochromically with the number of EDOT units from $509 \mathrm{~nm}$ for 29 to $576 \mathrm{~nm}$ for 31 while the oxidation potential decreases from 1.06 to $0.70 \mathrm{~V}$ indicating a corresponding increase of the HOMO level. Bi-layer tests devices of $28 \mathrm{~mm}^{2}$ have been realized by thermal evaporation of the molecules and $\mathrm{C}_{60}$. The cell based on compound 29 shows a $J_{\mathrm{sc}}$ of $3.51 \mathrm{~mA} \mathrm{~cm}^{-2}$ but a low $V_{\mathrm{oc}}$ of $0.35 \mathrm{~V}$, combined with a low FF these values lead to a PCE of $0.41 \%$. Compound 31 leads to a small increase of $P C E$ to $0.70 \%$ due essentially to an increase of $V_{\text {oc }}$ to $0.64 \mathrm{~V}$. Finally compound 30 represents an interesting trade-off leading to a $J_{\mathrm{sc}}$ of $5.40 \mathrm{~mA} \mathrm{~cm}{ }^{-2}$, a $V_{\text {oc }}$ of $0.83 \mathrm{~V}$ and a PCE of $2.02 \% .{ }^{[62]}$ Holemobility measurements by the space-charge-limited current method showed that compound $\mathbf{3 0}$ presents a mobility ca. three times larger than compound 31. As already observed for other classes of donors, at such low level of hole-mobility small improvements can produce a large increase of PCE. ${ }^{[32 b, 63]}$ Comparison of the optical spectra of compounds $\mathbf{3 0}$ and $\mathbf{3 1}$ in solution and in the solid state reveals again two opposite behaviors with respectively a broadening of the spectrum and red shift of $\lambda_{\max }$ for films of 30 and a blue shift of $\lambda_{\max }$ for 31 suggesting again different modes of aggregation $J$-aggregates for 30 and $H$-aggregates for 31. ${ }^{[62]}$ These results show that $J_{\mathrm{sc}}$ and PCE comparable to those obtained with longer nTs in advanced devices of smaller active area can be obtained with simple short-chain systems. However, they also point out the inherent difficulties of a judicious use of the EDOT unit for the design of functional $\pi$-conjugated systems.

Compared to the considerable amount of work devoted to the modification of the physical, chemical and electronic properties of $\mathrm{nTs}^{[64]}$ the design of $\mathrm{nTs}$ specifically devoted to OPV appears limited to the introduction of some simple<smiles>[R]c1ccc(-c2ccc(-c3ccc([R])s3)s2)s1</smiles>

24<smiles>[R]c1sc(-c2ccc(-c3sc([R])c4c3OCCO4)s2)c2c1OCCO2</smiles>

25<smiles>[R]c1sc(-c2sc(-c3sc([R])c4c3OCCO4)c3c2OCCO3)c2c1OCCO2</smiles>

26<smiles>[R7]COc1cc(-c2ccc(-c3sc([R])c4c3OCCO4)s2)sc1-c1ccc(-c2sc([R])c3c2OCCO3)s1</smiles>
27<smiles>[R]c1sc(-c2sc(-c3ccc(-c4sc(-c5sc([R])c6c5OCCO6)c5c4OCCO5)s3)c3c2OCCO3)c2c1OCCO2</smiles>

28<smiles>N#CC(C#N)=Cc1sc(-c2sc(-c3scc4c3OCCO4)c3c2OCCO3)c2c1OCCO2</smiles>

31

Figure 6. Chemical structures of compounds 24-31. 
electron-withdrawing groups or to a few combinations of thiophene with electron-donor or electron-acceptor units. Taking the unique combination of chemical versatility and electronic properties of $\mathrm{nTs}$ into account suggests that a broad field of investigation is still open for the synthesis of new simple and efficient nT-based donor structures.

\subsection{Oligoacenes}

Oligoacenes are among the first systems considered as organic semiconductors. Thus, the photogeneration of charge-carriers in anthracene and tetracene was investigated already during the sixties. ${ }^{[65,66]}$ However, it was only some thirty years latter that oligoacenes have been used as donor material for OPV cells. ${ }^{[67-72]}$ A heterojunction based on pentacene (32) (Figure 7) was mentioned in a 1998 conference paper but no detail was presented. ${ }^{[67]}$ Kippelen et al. have reported vacuum-deposited PHJ cells with pentacene as donor and $\mathrm{C}_{60}$ as acceptor. A thin layer of bathocuproine (BCP) was deposited between the $\mathrm{C}_{60}$ layer and the aluminium electrode as exciton blocker. Under white light illumination the device of $13 \mathrm{~mm}^{2}$ area gave a high $J_{\mathrm{sc}}$ of $15 \mathrm{~mA} \mathrm{~cm}^{-2}$ a $V_{\text {oc }}$ of $0.363 \mathrm{~V}$ with a FF of $50 \%$ indicating a power conversion efficiency of $2.70 \%{ }^{[68]}$ The spectral response showed an EQE of ca. $40 \%$ over a large spectral range with a maximum of $58 \%$ around $650 \mathrm{~nm}$. However, integration of the $E Q E$ spectrum led to an estimated $J_{\text {sc }}$ of $\sim 8.0 \mathrm{~mA} \mathrm{~cm}{ }^{-2}$ and a $P C E$ of $1.50 \% .{ }^{[68]}$ More recently Lane and coworkers reported a $J_{\text {sc }}$ of $7.59 \mathrm{~mA} \mathrm{~cm}^{-2}$ and a $V_{\text {oc }}$ of $0.24 \mathrm{~V}$ with $P C E=0.82 \%$ for a pentacene bilayer cell. ${ }^{[69]}$

Using tetracene (33) as donor, $\mathrm{C}_{60}$ as acceptor, and BCP as exciton blocking layer Yang et al. have realized PHJ cells with
$2.30 \% P C E, J_{\mathrm{sc}}=7.0 \mathrm{~mA} \mathrm{~cm}{ }^{-2}$ and $V_{\text {oc }}=0.58 \mathrm{~V} .^{[70]}$ The higher $V_{\text {oc }}$ compared to pentacene is due to the lower HOMO level of tetracene. It was suggested that the polycrystalline structure of the vacuum deposited tetracene film increased the D/A contacting area with $\mathrm{C}_{60}$ thus increasing the probability of exciton dissociation. ${ }^{[70]}$ Nunzi et al. have fabricated a BHJ by co-evaporation of pentacene and DP13 as acceptor. A maximum PCE of $0.54 \%$ with $J_{\mathrm{sc}}$ exceeding $5.0 \mathrm{~mA} \mathrm{~cm}^{-2}$ were reported. ${ }^{[71]}$ The same authors have used rubrene (34) as donor in a PHJ cell with $\mathrm{C}_{60}$ as acceptor. The device gave a $J_{\mathrm{sc}}$ of $5.30 \mathrm{~mA} \mathrm{~cm}^{-2}$ a $V_{\text {oc }}$ of $1.0 \mathrm{~V}$ and a PCE of $3.0 \% .{ }^{72]}$

Nuckolls et al. have synthesized 6,13-di(2-thienyl)pentacene (35) and used it as donor in PHJ cells. The donor was spincast on ITO substrates pre-coated with PEDOT:PSS and the device of $16 \mathrm{~mm}^{2}$ active area was completed by thermal evaporation of a $\mathrm{C}_{60}$ layer and an aluminium cathode. ${ }^{[73]}$ Under simulated solar light the cell gave a $J_{\mathrm{sc}}$ of $4.20 \mathrm{~mA} \mathrm{~cm}^{-2}$, a $V_{\text {oc }}$ of $0.63 \mathrm{~V}$ with a FF of $53 \%$ leading to a PCE of $1.40 \%$. Malliaras et al. have reported solution-processed multi-layer cells based on a pentacene solubilized by triisopropylsilylethynyl groups (36). After insertion of an exciton blocking layer, a PCE of $0.52 \%$ was obtained under white light illumination. ${ }^{\left[{ }^{[7]}\right.}$ More recently, the same group has used soluble anthradithiophene (37) to fabricate solution-processed $\mathrm{BHJ}$ cells using $\mathrm{PC}_{61} \mathrm{BM}$ as acceptor and dichlorobenzene as solvent. The donor led to the formation of spherulites in the bulk composite, and this process was found to improve the PCE. The devices delivered a $J_{\text {sc }}$ approaching $3.0 \mathrm{~mA} \mathrm{~cm}-2$, a $V_{\text {oc }}$ of $0.84 \mathrm{~V}$ and a $F F$ of $40 \%$ leading to a PCE of $1.0 \% .{ }^{[75]}$

Watkins et al. have synthesized soluble derivatives of dibenzo[b,def]chrysene (38). As underlined by the authors an advantage of these compounds is that unlike pentacene they<smiles>c1ccc2cc3cc4cc5ccccc5cc4cc3cc2c1</smiles>

32<smiles>c1ccc2cc3cc4ccccc4cc3cc2c1</smiles>

33<smiles>[R5][SiH2]C#Cc1c2cc3ccccc3cc2c(C#C[SiH2])c2cc3ccccc3cc12</smiles>

36<smiles>c1ccc(-c2c3ccccc3c(-c3ccccc3)c3c(-c4ccccc4)c4ccccc4c(-c4ccccc4)c23)cc1</smiles>

34<smiles>CCSC#Cc1c2cc3cc(CC)sc3cc2c(C#C[SiH2]C)c2cc3cc(CC)sc3cc12</smiles>

37<smiles>c1csc(-c2c3cc4ccccc4cc3c(-c3cccs3)c3cc4ccccc4cc23)c1</smiles>

35

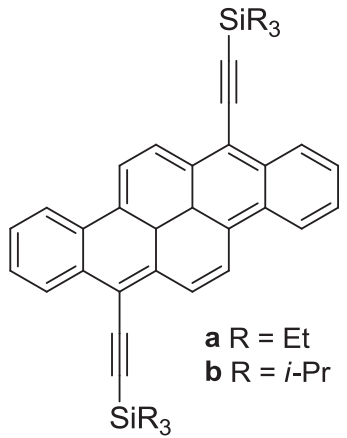

38

Figure 7. Chemical structures of compounds 32-38. 
do not undergo cycloaddition reactions with fullerene derivatives. ${ }^{[76]}$ Furthermore the compounds show a surprisingly high tolerance to impurities since materials with less than $92 \%$ purity still give devices with $\sim 1.40 \%$ PCE. BHJ cells of $20 \mathrm{~mm}^{2}$ active area were fabricated using $\mathrm{PC}_{61} \mathrm{BM}$ as acceptor and calcium/aluminium cathode. Materials based on 38a and $\mathbf{b}$ show a band gap of ca. $2.0 \mathrm{eV}$ and gave rather similar PV performances with slightly higher $V_{\text {oc }}$ and $F F$ for $38 \mathrm{~b}$ but lower $J_{\text {sc }}$. The best device obtained with donor 38a gave $J_{\mathrm{sc}}=6.55 \mathrm{~mA} \mathrm{~cm}^{-2}, V_{\mathrm{oc}}=$ $0.83 \mathrm{~V}, F F=0.41$ leading to a PCE of $2.25 \% .{ }^{[76]}$

Donors of the acenes series present the advantage of combining simple structure low molecular weight and high holemobility. However until now the modification of the chemical structure of these molecules has been mostly focused on the improvement of solubility and hole mobility in view of OFETs application. While the reactivity of linear oligoacenes against oxygen or fullerenes can be a source of problems, other small fused ring systems still relatively unexplored so far would certainly deserve a deeper attention from organic chemists.

\subsection{Squaraines Dyes}

Squaraine dyes are typically built by connecting two identical electron-donating groups to the strong electron acceptor squaric unit to produce D-A-D architectures. However unsymmetrical squaraines have also been developed. ${ }^{[77]}$ Theoretical calculations have suggested that both the ground and the singlet excited state of squaraines involve significant internal charge transfer. Squaraines generally absorb in the visible or NIR region with very high molar extinction coefficients. Combined with an excellent photostability, these absorption properties have given rise to many applications in the area of electronic and photonic devices. ${ }^{[77]}$

Squaraines have been used as active material in some of the earliest prototypes of OPV cells. Thus in 1976, Merritt and Hovel reported Schottky-barrier solar cells made from thin films of the hydroxy squarylium (39). Amorphous and polycrystalline films prepared by evaporation and solution casting, showed strong absorption over the entire visible spectrum. The highest $P C E$ under white-light illumination was $0.10 \%$ at $0.14 \mathrm{~mW} \mathrm{~cm} \mathrm{~cm}^{-2}$ incident light intensity, decreasing to $0.02 \%$ at $135 \mathrm{~mW} \mathrm{~cm}{ }^{-2}$. Under $850 \mathrm{~nm}$ monochromatic light $\left(1 \mathrm{~mW} \mathrm{~cm}{ }^{-2}\right)$ a quantum efficiency of $2.30 \%$ and a PCE of $0.20 \%$ were reported. ${ }^{[78]}$ During the nineties squaric acid derivatives have been used in PV devices prepared by the Langmuir-Blodgett technique ${ }^{[79]}$ and used as building blocks for the synthesis of some of the first examples of donor-acceptor low band gap conjugated polymers. ${ }^{80]}$

In recent years, squaraines have been a focus of renewed interest as donor materials for OPV ${ }^{[81-89]}$ Thus, Forrest et al. have used 2,4-bis[4-(N,N-diisobutylamino)-2,6-dihydroxyphenyl] squaraine (40) (Figure 8) in vacuum deposited $\mathrm{PHJ}$ cells with $\mathrm{C}_{60}$ as acceptor. The molecule was purified several times by sublimation. Solid-state films show an absorption maximum at $700 \mathrm{~nm}$ and an absorption coefficient of $2.0 \times 10^{5} \mathrm{~cm}^{-1}$. PHJ cells of $0.79 \mathrm{~mm}^{2}$ active area $\left(\mathrm{ITO} / 40 / \mathrm{C}_{60} / \mathrm{BCP} / \mathrm{Al}\right)$ were fabricated by vacuum deposition with thickness of the donor layers varying from 6.5 to $20 \mathrm{~nm}$. The highest PCE was observed with the thinnest films while the singly purified donor led to lower values. The best devices fabricated with doubly purified donor gave a $J_{\mathrm{sc}}$ of
$7.01 \mathrm{~mA} \mathrm{~cm}^{-2}$ a $V_{\text {oc }}$ of $0.76 \mathrm{~V}$ and a FF of $56 \%$ leading to PCE of $3.10 \% .{ }^{[81]}$ The same group used donor 40 to fabricate solution-processed BHJ cells with $\mathrm{PC}_{71} \mathrm{BM}$ and reported a $J_{\mathrm{sc}}$ of $8.85 \mathrm{~mA} \mathrm{~cm}^{-2}$ a $V_{\text {oc }}$ of $0.89 \mathrm{~V}$ and a PCE of $2.70 \% .^{[82]}$ More recently these authors have described solution-processed $\mathrm{BHJ}$ cells fabricated with donor 40 and $\mathrm{PC}_{71} \mathrm{BM}$ as acceptor in a 1:6 ratio. ${ }^{[83]}$ These active blends were submitted to solvent annealing and it was found that $10 \mathrm{~min}$ exposure of the blend to dichloromethane (DCM) vapor produces a considerable increase of the cell performances with a $J_{\mathrm{sc}}$ of $12.0 \mathrm{~mA} \mathrm{~cm} \mathrm{~cm}^{-2}$, a $V_{\text {oc }}$ of $0.92 \mathrm{~V}$ and a $P C E$ of $5.20 \pm 0.30 \%$. However, PCE decreased to $3.20 \%$ after 2 min further exposure to DCM vapor. ${ }^{[83]}$

Yang et al. have also employed squaraine $\mathbf{4 0}$ to produce $\mathrm{HHJ}$ cells of structure ITO/ $\mathrm{MoO}_{3} / 40+\mathrm{PC}_{71} \mathrm{BM} / \mathrm{BCP} / \mathrm{Al}$ of $4 \mathrm{~mm}^{2}$ area. Optimization of the $\mathrm{D} / \mathrm{A}$ ratio led to a device with a $J_{\mathrm{sc}}$ of $10.6 \mathrm{~mA} \mathrm{~cm}^{-2} \mathrm{a} V$ oc $_{\text {of }} 0.94 \mathrm{~V}$ and a PCE of $4.0 \%$. The relatively low $F F$ was attributed to a strong charge recombination. ${ }^{[84]}$ Fan et al. have used unsymmetrical squaraines (41) and (42) to fabricate bilayer $\mathrm{PHJ}$ cells with $\mathrm{C}_{60}$ as acceptor. Donor 41 led to a highest PCE of $0.59 \%$ while better results were obtained with the naphtyl derivative 42 which gave a PCE of $1.01 \%$ with $J_{\mathrm{sc}}=$ $6.80 \mathrm{~mA} \mathrm{~cm}^{-2}$ but relatively low $F F(0.33)$ and $V_{\text {oc }}(0.44) V^{[85]}$

The group of Würthner has synthesized two series of symmetrical squaraines $(43,44)$ as donors for solution-processed $\mathrm{BHJ}$ cells with $\mathrm{PCB}_{61} \mathrm{M}$ as acceptor. ${ }^{[86]}$ Analogues to 43 gave $J_{\mathrm{sc}}$ in the range of $1.0 \mathrm{~mA} \mathrm{~cm}{ }^{-2}$ and low PCE $(0.15 \%$ in the best case). Introduction of a dicyanovinyl group at the squaric acid of analogues of 44 causes a ca. $40 \mathrm{~nm}$ red shift of $\lambda_{\max }$ and produces a strong increase of $J_{\mathrm{sc}}$ which after thermal annealing, reaches a value of $12.60 \mathrm{~mA} \mathrm{~cm}^{-2}$ with a PCE of $1.79 \%$. This high current density was attributed to the improved hole-mobility of the material after annealing, as confirmed by the increase of the OFET mobility from $1.5 \times 10^{-5}$ to $1.3 \times 10^{-3} \mathrm{~cm}^{2} \mathrm{~V}^{-1} \mathrm{~s}^{-1}$. Crystallographic data obtained on single crystals have confirmed the dense packing of the molecules. However the PCE of these cells was limited by the relatively low $V_{\text {oc }}$ of the devices (0.31 V) for 44. ${ }^{[86]}$

Unsymmetrical squaraines (45) and (46) were recently synthesized by Yang et al. ${ }^{[87]}$ Replacement of the dialkyl amino group of 45 by a carbazoyl one (46) leads to a $0.40 \mathrm{eV}$ decrease of the HOMO level and hence to a large increase of the $V_{\text {oc }}$ of the resulting OPV cells. Solution-processed $\mathrm{BHJ}$ cells were fabricated with $\mathrm{PC}_{71} \mathrm{BM}$ as acceptor in an optimized 1:5 w/w ratio. The cells delivered $J_{\mathrm{sc}}$ of 5.40 and $5.80 \mathrm{~mA} \mathrm{~cm}{ }^{-2}$ for 45 and 46 respectively but rather low FF of 38 and $36 \%$ leading to PCE values of 1.54 and $2.32 \% .{ }^{[87]}$ As expected the introduction of the carbazoyl unit in $\mathbf{4 6}$ produces a large increase of $V_{\text {oc }}$ from 0.75 to $1.12 \mathrm{~V}$ a value approaching the highest voltages reported so far for OPV cells based on small molecules namely $1.15^{[88]}$ and $1.17 V^{[58]}$ Besides the above discussed molecules some examples of squaraines leading to PCE up to ca. $2.0 \%$ have also been reported in recent years but their much higher molecular weight put them out of the scope of this survey. ${ }^{[89,90]}$

Subject to a renewal of interest in the context of the design of molecular donors for OPV, squaraines present several interesting features such as very high absorption coefficients, good photochemical stability and possibility to design small molecular structures. Until now the reported PCE values obtained with squaraines are on the whole inferior to those obtained 


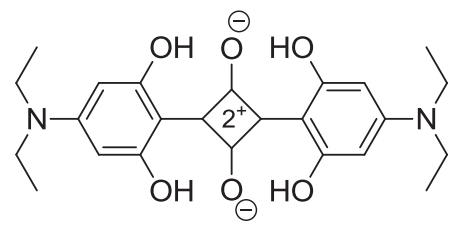

39<smiles>CCN1/C(=C/C2=C(O)/C(=C\C3=[N+]([O-])c4ccc(C(=O)O)cc4C3(C)C)C2=O)C(C)(C)c2ccccc21</smiles><smiles>CC(C)N1C(=CC2=C(O)C(=CC3=[N+](C(C)C)c4ccccc4C3(C)C)C(=O)C2=O)C(C)(C)c2ccccc21</smiles>

43

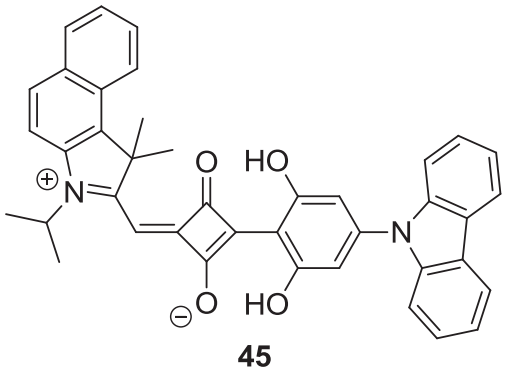

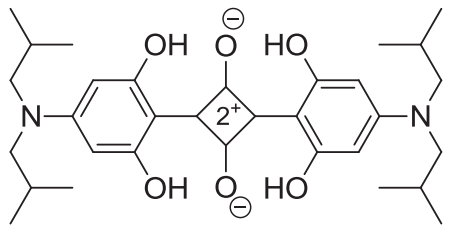

40
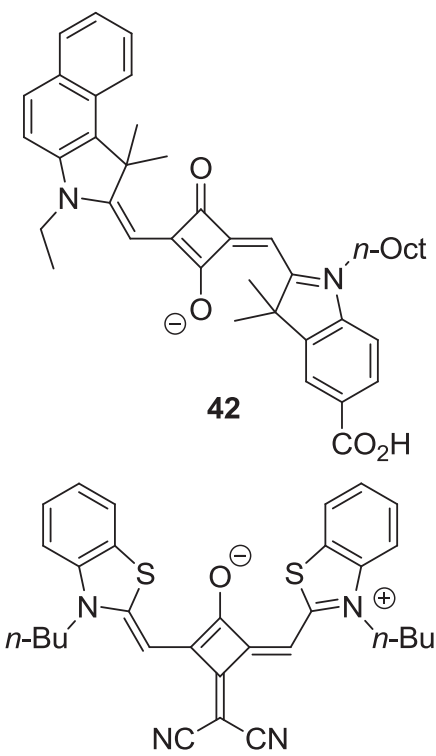

44

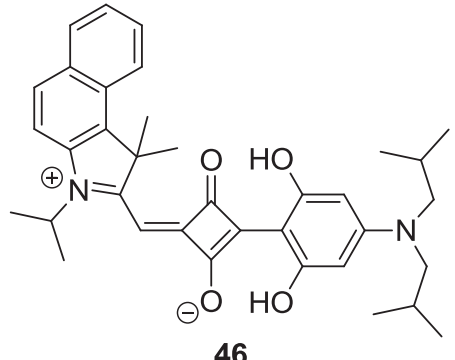

46 thermal evaporations. Under white light illumination at $78 \mathrm{~mW} \mathrm{~cm}{ }^{-2}$ the cell gave a $J_{\text {sc }}$ of $1.80 \mathrm{~mA} \mathrm{~cm}^{-2}$, a $V_{\text {oc }}$ of $1.20 \mathrm{~V}$ and a FF of $25 \%$ leading to a respectable $P C E$ of $0.70 \%$ which is certainly one of the highest value obtained during the pioneering years of OPV.$^{[4]}$ The photocurrent action spectrum showed a broad band extending from 400 to $600 \mathrm{~nm}$ with a maximum around $520 \mathrm{~nm}$. An exciton diffusion length of $60 \AA$ was determined by analyzing the photocurrent action spectra using a theoretical model. It was reported that these devices have higher efficiencies when a very thin interfacial oxide layer was formed between the aluminium electrode and the merocyanine. ${ }^{[92]}$

Merocyanines have been recently revisited as donor materials for OPV by Würthner, Meerholz et al. who synthesized and investigated several series of these molecules. ${ }^{[93-96]}$ In a paper published in 2008 two series of merocyanines with 2-aminothiophene (48) or indoline (49) as donor block were used in BHJ solar cells. The active layer consisted of composite films dye- $\mathrm{PC}_{61} \mathrm{BM}$ of $40-100$ $\mathrm{nm}$ thickness with an optimum weight ratio PCBM-donor of $\sim 70 \%$, sandwiched between an ITO/PEDOT:PSS electrode and an aluminium cathode. The $V_{o c}$ was correlated to the contact potential difference between films of the dyes and gold measured by Kelvin probe. Some discrepancies observed between $V_{\text {oc }}$ and the HOMO level estimated from electrochemical data in solution were attributed to different mode of aggregation in solution. The largest $V_{\text {oc }}$ value of $0.90 \mathrm{~V}$ was observed for compound 49. In the aminothiophene series, the best results were obtained with compound 48 which led to a $V_{o c}$ of $0.73 \mathrm{~V}$ and a $J_{\mathrm{sc}}$ of $4.0 \mathrm{~mA} \mathrm{~cm}{ }^{-2}$ with a $P C E$ of $0.91 \% \cdot{ }^{\left[{ }^{[9]}\right]}$ Cells based on indoline donors gave larger $J_{\mathrm{sc}}$ namely 5.30 and $6.30 \mathrm{~mA} \mathrm{~cm}^{-2} \mathrm{f}$ with other classes of molecular donors. In particular limited hole-transport properties seem to represent a major problem as suggested by the generally observed low FF, despite the small active area of most of the reported devices. ${ }^{[91]}$ However, the synthesis of squaraine-based molecules specifically designed for OPV has been so far limited to a few examples and it may be premature to draw definitive conclusions about the potential of this class of compounds for PV conversion.

\subsection{Merocyanines Dyes}

Merocyanines dyes are another class of chromophores that have been investigated at the early stages of research on OPV. In 1978 Morel et al. reported a Schottky diode based on thin films of merocyanine (47) (Figure 9) sandwiched between aluminium and silver electrodes and fabricated by successive or 49 and 50 respectively and $V_{\text {oc }}$ of 0.90 and $0.76 \mathrm{~V}$ leading to $P C E$ of 1.54 and $1.74 \%$. However the rather low FF values found for all of the cells (ca. $30 \%$ ) was taken as an indication for insufficient charge-transport. ${ }^{[93]}$ Compound 49 was subsequently used to fabricate a tandem cell based on two identical junctions in series. The resulting tandem cell gave $P C E$ of $4.80 \%$ and a very high voltage of $2.10 \mathrm{~V} \cdot{ }^{[94]}$ More recently, starting from the structure of compound 49, these authors have designed two new molecules in which the donor block is rigidified by a covalent bridge $(51,52) \cdot{ }^{[94]} \mathrm{BHJ}$ cells ITO/ PEDOT:PSS/Donor: $\mathrm{PC}_{61} \mathrm{BM} / \mathrm{Al}$ were fabricated by solution process, the optimal thickness of the active layer was found in the 50-60 nm range. Comparison of the results obtained with 49 and its bridged versions showed that for $\mathbf{5 1}, J_{\mathrm{sc}}$ increases from 5.30 to $6.25 \mathrm{~mA} \mathrm{~cm}^{-2}$, but $V_{\text {oc }}$ decreases from 0.90 to $0.78 \mathrm{~V}$ resulting in a lower PCE of $1.43 \%$. In contrast, for $\mathbf{5 2}, J_{\mathrm{sc}}$ and $V_{\mathrm{oc}}$ increase to $8.24 \mathrm{~mA} \mathrm{~cm}{ }^{-2}$ and $0.94 \mathrm{~V}$ raising $P C E$ to 
<smiles>[Z17]CN1/C(=C/C=C2/Sc3ccccc3N2CC)C(=O)N1CC(=O)O</smiles><smiles>CCCCC(CC)CN1C(=O)C(=Cc2ccc(N(CCCC)CC(C)C)s2)C(C)=C(C#N)C1=O</smiles><smiles>CC1(C)C(=CC=C2C(=O)c3ccccc3C2=C(C#N)C#N)N2CCc3cccc1c32</smiles>

51<smiles>CC(C)Cn1/c(=C/C=C2\C(=O)c3ccccc3C2(C)C)c(=C(C#N)C#N)c2ccccc21</smiles>

49<smiles>CC1(C)C(=CC=C2C(=O)c3ccccc3C2=C(C#N)C#N)N2CCCc3cccc1c32</smiles>

52<smiles>CC(C)(C)c1nc(=C(C#N)C#N)s/c1=C\C=C1/N(Cc2ccccc2)c2ccccc2C1(C)C</smiles>

50

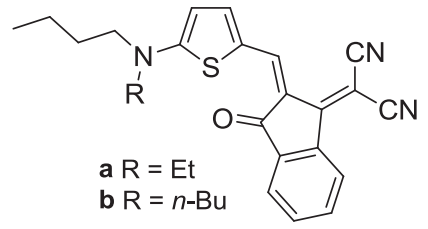

53

Figure 9. Chemical structures of compounds 47-53.

2.59\%. Again the low FF values were attributed to the low hole-mobility of the donors a conclusion supported by the fact that compound 51 leads to both the highest hole-mobility and FF values. ${ }^{[95]}$

Compound 52 has been used for the fabrication of $\mathrm{HHJ}$ cell by co-evaporation with $\mathrm{C}_{60}$ on an ITO electrode modified by $\mathrm{MoO}_{3}$, the device was completed by an exciton blocking layer of BPhen. Cells of $8 \mathrm{~mm}^{2}$ area with $J_{\mathrm{sc}}$ values of $\sim 12.00 \mathrm{~mA} \mathrm{~cm}^{-2}$ were obtained with both PEDOT:PSS and $\mathrm{MoO}_{3}$ buffer layers however, the latter led to better $V_{\mathrm{oc}}, F F$ and hence $P C E$. The best device gave a $J_{\mathrm{sc}}$ of $12.40 \mathrm{~mA} \mathrm{~cm}^{-2}$, a $V_{\text {oc }}$ of $0.962 \mathrm{~V}$ and a $P C E$ of $6.10 \%$ which represents one of the highest value reported so far for vacuum deposited OPV cells, especially when considering the simplicity of the device. Interestingly the $F F$ values $(-50 \%)$ were significantly improved compared to solution-processed $\mathrm{BHJ}$ cells. ${ }^{\left[{ }^{96]}\right.}$ In parallel, the group has reported the synthesis of new series of merocyanines with dialkylaminothiophenes as donor block (53). ${ }^{[97]}$ The use of different acceptor units allowed to modulate the $\lambda_{\max }$ from $517 \mathrm{~nm}$ for indandione to $660 \mathrm{~nm}$ for bis-indandione. The energy level of the frontier molecular orbitals estimated by $\mathrm{CV}$ showed that varying the strength of the acceptor essentially affects the LUMO level. The dyes have been evaluated in solution-processed $\mathrm{BHJ}$ cells with $\mathrm{PC}_{61} \mathrm{BM}$ as acceptor in simple devices ITO/PEDOT:PSS/donor $+\mathrm{PC}_{61} \mathrm{BM} /$ Al. The cells gave voltage comprised between 0.47 and $0.96 \mathrm{~V}$ correlated with the HOMO level of the donor and $J_{\mathrm{sc}}$ values of 4.00 to $8.30 \mathrm{~mA} \mathrm{~cm}^{-2}$. The best results were obtained with donor 53a which combined the highest values of $V_{o c}, F F$ and $J_{\text {sc }}$ led to a $P C E$ of $3.0 \%$. Switching to $\mathrm{PC}_{71} \mathrm{BM}$ as acceptor and replacing aluminium by a $\mathrm{Ba} / \mathrm{Ag}$ cathode produced a further improvement of performances with $J_{\mathrm{sc}}=10.20 \mathrm{~mA} \mathrm{~cm}^{-2}$, $V_{\mathrm{oc}}=1.0 \mathrm{~V}$ and $P C E=4.50 \%$. A control experiment using DPP 2 instead of 53a as donor gave slightly lower performances
$(P C E=4.10 \%)$ while requiring a higher dye content and $10 \mathrm{~min}$ annealing at $110{ }^{\circ} \mathrm{C} .{ }^{[97]}$

Besides the demonstration that highly dipolar D-A chromophores can lead to good PV performances, the results obtained with some of these merocyanines confirm that high PCE can be achieved with simple and small molecules in fact with a MW of 387 compound 53a ranks among the simplest and lightest efficient donors reported so far.

\subsection{Triphenylamine-Based Small Donors}

Triphenylamine (TPA) derivatives are among the first donors developed for solution processed molecular BHJ.[28b,30,61] Whereas rather large and heavy molecular systems were investigated in initial works, in the past few years several groups have synthesized smaller TPA-based donor molecules for both solution-processed and vacuum deposited cells. ${ }^{[98-106]}$ Wong et al. have reported a D-A system in which the TPA block is connected to a dicyanovinyl acceptor by a dithienosilole group (54) (Figure 10). ${ }^{[98]}$ The compound shows a $\lambda_{\max }$ of $537 \mathrm{~nm}$ in DCM with a molar absorption coefficient of $\varepsilon=45800 \mathrm{M}^{-1} \mathrm{~cm}^{-1}$. HHJ solar cells were realized by vacuum co-deposition of the donor and fullerene: (ITO/MoO $/ \mathrm{D}+\mathrm{C}_{60}$ or $\mathrm{C}_{70} 1: 1 / \mathrm{C}_{60}$ or $\mathrm{C}_{70} / \mathrm{BCP} / \mathrm{Ag}$. The cell fabricated with $\mathrm{C}_{60}$ as acceptor gave a $V_{\text {oc }}=0.80 \mathrm{~V}$, a $J_{\text {sc }}$ of $6.56 \mathrm{~mA} \mathrm{~cm}^{-2}, F F=$ 0.46 leading to a $P C E$ of $2.69 \%$. Replacement of $\mathrm{C}_{60}$ by $\mathrm{C}_{70}$ improved all parameters $\left(V_{\mathrm{oc}}=0.83 \mathrm{~V}, J_{\mathrm{sc}}=9.53 \mathrm{~mA} \mathrm{~cm}^{-2}, F F=\right.$ $48 \%)$ thus raising $P C E$ to $3.82 \%$. The contribution of light absorption by $\mathrm{C}_{70}$ in the visible region was clearly apparent in the EQE spectrum. ${ }^{[98]}$

The same group has introduced a D-A-A molecule in which insertion of the electron acceptor BzT group in the conjugated 


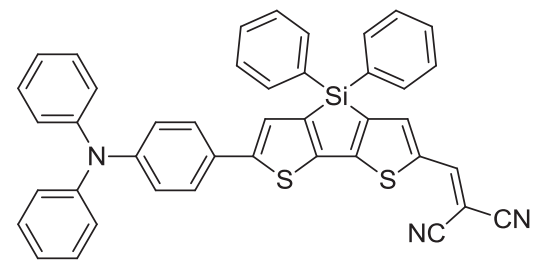

54

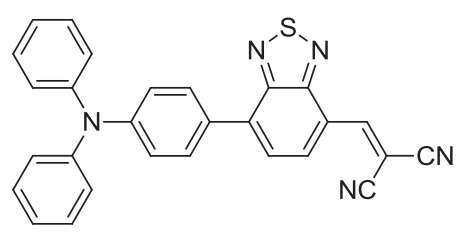

57

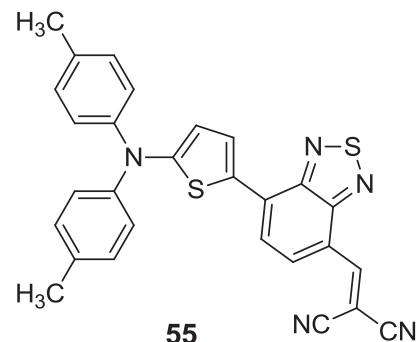

55<smiles>Cc1ccc(N(c2ccc(C)cc2)c2ccc(-c3ncc(C=C(C#N)C#N)cn3)s2)cc1</smiles>

56<smiles>C/C(C#N)=C\c1ccc(-c2ccc(N(c3ccccc3)c3ccc(C)cc3)cc2)c2nsnc12</smiles>

58

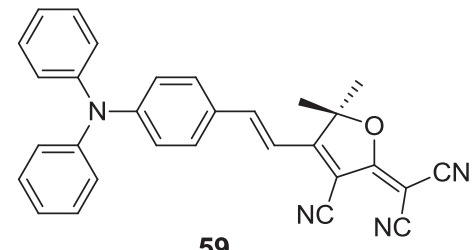

59

Figure 10. Chemical structures of compounds 54-59.

system (55) contributes to a further bathochromic shift of $\lambda_{\max }$ to $663 \mathrm{~nm}$ in solution and $684 \mathrm{~nm}$ in films. Two types of $\mathrm{HHJ}$ devices were used for evaluation ITO/ $\mathrm{MoO}_{3} / \mathrm{D} / \mathrm{D}+\mathrm{A}(1: 1) / \mathrm{A} /$ $\mathrm{BCP} / \mathrm{Ag}$. The cell with $\mathrm{C}_{60}$ as acceptor gave a $V_{\text {oc }}$ of $0.80 \mathrm{~V}$, a $J_{\mathrm{sc}}$ of $11.40 \mathrm{~mA} \mathrm{~cm}^{-2}, F F=0.48$, and a PCE of $4.41 \%$. Replacement of $\mathrm{C}_{60}$ by $\mathrm{C}_{70}$ led to an increase of $J_{\text {scto }} 14.68 \mathrm{~mA} \mathrm{~cm}^{-2}$ and to a $P C E$ to $5.81 \% .{ }^{[99]}$ In order to increase the $V_{\text {oc }}$ the BzT acceptor block of compound 55 has been replaced by a pyrimidine (56) with a HOMO $0.16 \mathrm{eV}$ deeper than 55. ${ }^{[100]}$ This new compound absorbs at $556 \mathrm{~nm}$ in solution with a $\varepsilon$ of $53900 \mathrm{M}^{-1} \mathrm{~cm}^{-1}$. Vacuum-deposited $\mathrm{HHJ}$ cells with an intermediate co-evaporated $\mathrm{D}+\mathrm{A}$ active layer and $\mathrm{MoO}_{3}$ as $\mathrm{HTL}, \mathrm{C}_{70}$ as acceptor, BCP as exciton blocking layer and silver cathode gave a $V_{\text {oc }}$ of $0.95 \mathrm{~V}$ and a $J_{\mathrm{sc}}$ of $12.10 \mathrm{~mA} \mathrm{~cm} \mathrm{~cm}^{-2}$ which combined with a $F F$ of $56 \%$ gave a PCE of $6.40 \% .{ }^{[100]}$ More recently Wong et al. have attempted to define a trade-off between deep HOMO level and hence high cell voltage and the density of photocurrent and hence the number of absorbed solar photons. To this end they synthesized two new D-A-A donors (57) and (58) in which the thienyl unit of compound 55 is replaced by a phenyl ring. This modification produces a blue shift of $\lambda_{\max }$ from 663 to $570 \mathrm{~nm}$ between compounds 55 and 58 (684 to 595 for films). When used as donor in the above described co-evaporated HHJ cell of $2.5 \mathrm{~mm}^{2}$ with $\mathrm{C}_{70}$ as acceptor compound 58 produces a $J_{\mathrm{sc}}$ of $13.48 \mathrm{~mA} \mathrm{~cm}^{-2}$, a $V_{\text {oc }}$ of $0.93 \mathrm{~V}, F F=53 \%$ and a maximum $P C E=6.80 \%$ which ranks among the highest reported so far for a vacuum-deposited single junction cell. ${ }^{101]}$

Prasad et al. have described the synthesis of two TPA-based D-A systems and used them as donor in solution processed BHJ cells of $4.25 \mathrm{~mm}^{2}$, (ITO/PEDOT:PSS/Donor:acceptor/ LiF-Al), using $\mathrm{PC}_{61} \mathrm{BM}$ or $\mathrm{PC}_{71} \mathrm{BM}$ as acceptor. The best devices fabricated with compound 59 and $\mathrm{PC}_{71} \mathrm{BM}$ gave a $J_{\mathrm{sc}}$ of $8.44 \mathrm{~mA} \mathrm{~cm}^{-2}, V_{\text {oc }}$ of $0.93 \mathrm{~V}, F F=0.30$ and a PCE of $2.44 \% .{ }^{[102]}$

The star-shaped compound 1 (Figure 11) has been recently revisited by Bernède et al. who reported vacuum deposited $\mathrm{PHJ}$ cell of $10 \mathrm{~mm}^{2}\left(\mathrm{ITO} / \mathrm{MoO}_{3}-\mathrm{CuI} / \mathbf{1} / \mathrm{C}_{60} / \mathrm{Al}\right)$ with a $J_{\mathrm{sc}}$ of
$6.60 \mathrm{~mA} \mathrm{~cm}^{-2}, V_{\text {oc }}$ of $0.73 \mathrm{~V}$, a FF of $55 \%$ and PCE of $2.50 \% .{ }^{[103]}$ On this basis compound 1 was used as starting point for the development of new series of donors of simplified structure and reduced molecular weight. A first step has consisted in the removal of two branches of compound 1 to obtain compound 60 a. This compound absorbs at $501 \mathrm{~nm}$ with a $\varepsilon$ of $34000 \mathrm{M}^{-1} \mathrm{~cm}^{-1}$. A $28 \mathrm{~mm}^{2} \mathrm{PHJ}$ cell ITO/PEDOT:PSS $/ 60 \mathrm{a} / \mathrm{C}_{60} / \mathrm{Al}$ gives a $J_{\mathrm{sc}}$ of $5.77 \mathrm{~mA} \mathrm{~cm}^{-2}$, a $V_{\text {oc }}$ of $0.92 \mathrm{~V}$ and a $F F$ of $42 \%$ leading to a PCE of $2.53 \%{ }^{[104]}$

In order to modify the electronic properties of compound $60 a$, the dicyanovinyl acceptor group has been fastened to the thiophene ring by an ortho-phenylene bridge $(60 \mathrm{~b})$. This modification produces a $110 \mathrm{~nm}$ red shift of $\lambda_{\max }$ to $611 \mathrm{~nm}$ while the LUMO level decreases from -3.79 to $-4.22 \mathrm{eV}$ as indicated by the $0.43 \mathrm{~V}$ positive shift of the reduction peak in the CV. Concurrently, the reduction wave which is irreversible for $60 \mathrm{a}$ becomes fully reversible for $\mathbf{6 0 b}$. These effects have been attributed to the stabilization of the radical-anion by aromatization of the cyclopentadiene ring upon reduction. ${ }^{[104]}$ Comparison of the performances of compound 60a and 60b in PHJ cells shows that the bridging produces a small decrease of $J_{\mathrm{sc}}$ to $5.77 \mathrm{~mA} \mathrm{~cm} \mathrm{~cm}^{-2}$ but an increase of $V_{\text {oc }}$ and $F F$ to $0.97 \mathrm{~V}$ and $52 \%$ respectively, resulting in an increase of $P C E$ to $2.97 \% .{ }^{105]}$

A different approach has been developed in the case of compounds $\mathbf{6 1}$ and $\mathbf{6 2}$ in which the dicyanovinyl acceptor group and the thiophene ring are bridged by an ethylene loop (61b and $\mathbf{6 2 b}) \cdot{ }^{[106]}$ Based on previous results on dithienylethylenebased systems, this modification was expected to produce a red shift of $\lambda_{\max }$ and an increase of the HOMO level. ${ }^{[107]}$ However in both cases the bridging of the system produces the opposite effect with a 25-35 nm blue shift of $\lambda_{\max }$. On the other hand, CV shows that bridging does not change the oxidation potential but produces a ca. $0.20 \mathrm{~V}$ negative shift of the reduction potential corresponding to a equivalent increase of the LUMO level. The four compounds have been used as donor in $\mathrm{PHJ}$ cells using spun-cast films of donor and vacuum-deposited $\mathrm{C}_{60}$. For both 

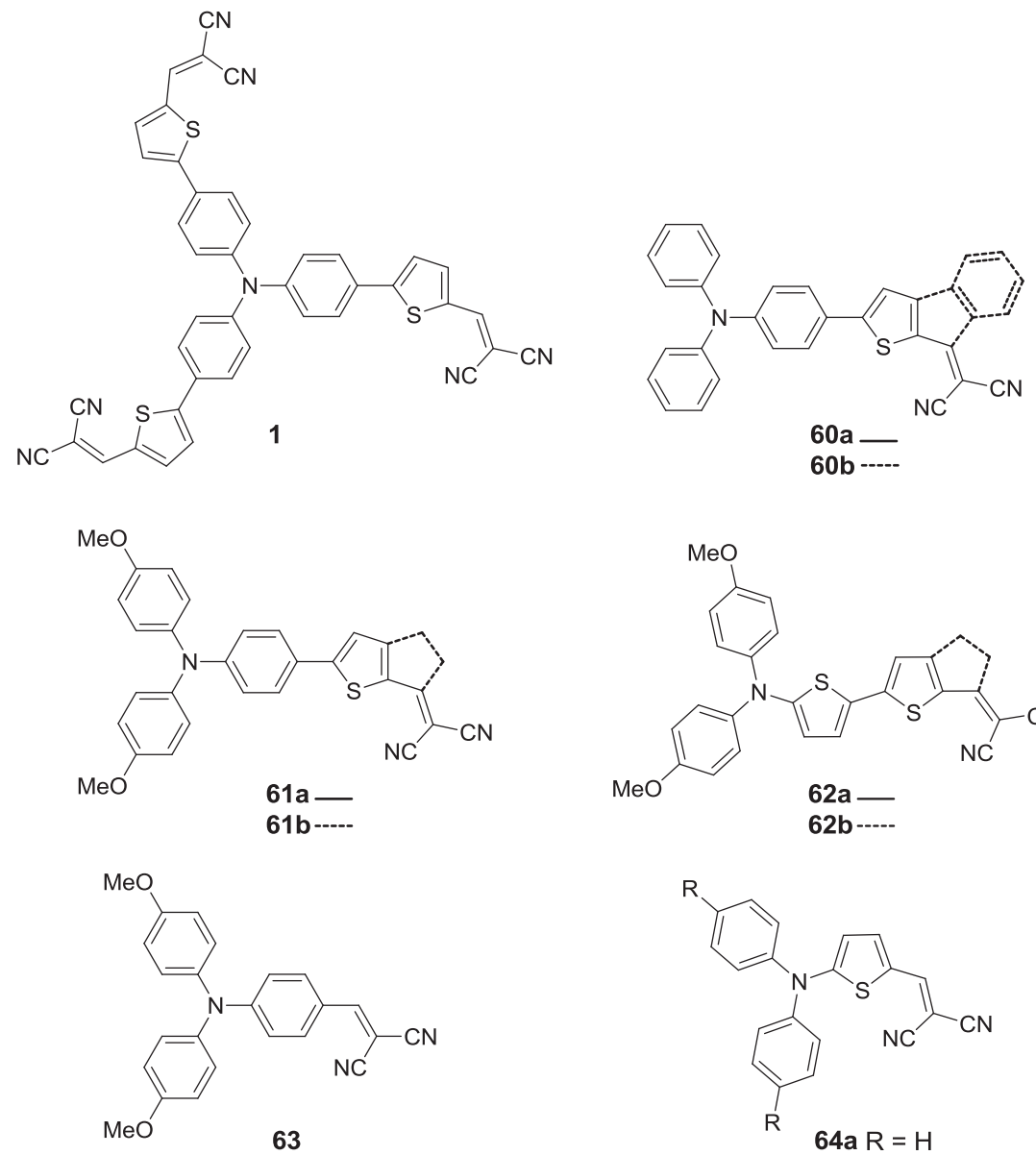

63
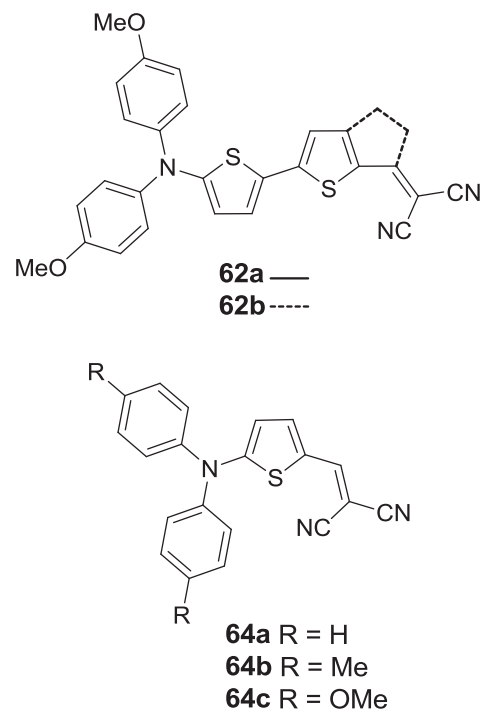

Figure 11. Chemical structures of compounds 60-64.

performances, compounds (63) and (64) that consist of a simple triarylamine donor block with a dicyanovinyl acceptor group have been synthesized and evaluated in PHJ cells. ${ }^{[109]}$ Due to their small conjugation length these compounds absorb at relatively short wavelengths (450-475 $\mathrm{nm}$ ) however, as already observed,[101,105] replacement of one of the phenyl group by a thiophene produces a significant red shift of $\lambda_{\max }$ from 446 for 63 to $475 \mathrm{~nm}$ for 64c. PHJ cells of $28 \mathrm{~mm}^{2}$ were fabricated by spin-casting a film of the donor on ITO substrate pre-coated with PEDOT:PSS followed by vacuum deposition of $\mathrm{C}_{60}$ and aluminium. Under white light illumination compound 63 gives a $J_{\mathrm{sc}}$ of $3.04 \mathrm{~mA} \mathrm{~cm}-2$ and a PCE of $0.85 \%$. The introduction of a thiophene in the structure improves these results to $5.40 \mathrm{~mA} \mathrm{~cm}^{-2}$ and $1.64 \%$ for $64 \mathrm{~b}$ while the unsubstituted donor $64 \mathrm{a}$ gave a $J_{\mathrm{sc}}$ of $6.80 \mathrm{~mA} \mathrm{~cm}^{-2}$, a $V_{\text {oc }}$ of $0.65 \mathrm{~V}$ and a $F F$ of $39 \%$ leading to a PCE of $1.92 \% .{ }^{[109]}$ The EQE spectra showed high conversion efficiency up to $50-60 \%$ in the absorption domain of the donors however, the light-harvesting properties of these molecules are clearly limited by their large band gap (ca. $2.20 \mathrm{eV}$ based on long wavelength absorption onset at ca. $560 \mathrm{~nm}$ for 63a). It is nevertheless remarkable that such a simple molecule can lead to performances and in particular $J_{\mathrm{sc}}$ comparable to those obtained with much heavier and more complex structures implemented in sophisticated devices of much smaller active area. couples of compounds bridging produces counter-acting effects namely a decrease of $J_{\text {sc }}$ from 5.88 to $4.87 \mathrm{~mA} \mathrm{~cm}^{-2}$ for $\mathbf{6 1 a - b}$ and from 7.23 to $5.50 \mathrm{~mA} \mathrm{~cm}{ }^{-2}$ for $62 \mathrm{a}-\mathrm{b}$ but a significant increase of $F F$ ( 32 to $50 \%$ for 61 and 39 to $52 \%$ for 62 ) and $V_{\text {oc }}(0.70$ to $0.82 \mathrm{~V}$ for 61 and 0.59 to 0.67 for 62 ) that results in an increase of PCE to 2.23 and $2.12 \% .{ }^{[106]}$ These results show that besides classical substitution by donor and/or acceptor groups, the covalent bridging of D-A chromophores represents an interesting approach for the modulation of the electronic properties at a moderate cost in terms of increase of size and molecular weight. An interesting specificity of compounds 60-62 is that they can be processed from solutions or by vacuum deposition. In a further investigation of the potentialities of these compounds a $28 \mathrm{~mm}^{2} \mathrm{HHJ}$ has been fabricated using a co-evaporated film of 60a and $\mathrm{C}_{60}$ sandwiched between thin layers of pure donor and acceptor. The cell gave a $\mathrm{V}_{\mathrm{oc}}$ of $1.0 \mathrm{~V} \mathrm{a} J_{\mathrm{sc}}$ of $6.30 \mathrm{~mA} \mathrm{~cm}^{-2}$, a $F F$ of $64 \%$ leading to a PCE of $4.0 \%$ results that clearly underlines the potential of this class of small molecules. ${ }^{[108]}$

As shown by many of the above discussed compounds, interesting PV performances can be obtained using relatively simple and small active molecules. In an attempt to explore the limit of size still compatible with the production of significant PV

\section{Conclusion and Perspectives}

During almost four decades, research on OPV has progressed using a few standard materials which were not initially designed for this purpose. In this already long story the contribution of chemistry is relatively recent since the first low band gap polymers or molecules specifically designed for OPV were synthesized only in 2001-2003. ${ }^{[2,110]}$ In fact it is only during the past few years that new classes of active materials have permitted to surpass the performances of standard materials such as CuPc or P3HT. These recent advances of the chemistry of OPV materials associated with intensive multi-disciplinary efforts have generated impressive progress that have definitively established the scientific credibility of OPV. However, an almost exclusive focus on the competition for higher PCE, which became also the main if not unique, criterion for evaluation of research on OPV, could have some deleterious consequences for the future of the field. In fact the impressive increase of the PCE achieved in a relatively short time has mobilized an increasing sophistication of the chemistry of active materials and of device technology. The most efficient polymeric and molecular donors have complex molecular structures that require multi-step 
synthesis thus leading to limited overall yields and high final costs. On the other hand, the multiple tailored buffer layers with optimized thickness and doping levels inserted in advanced devices, the replacement of $\mathrm{C}_{60}$ by the ca. ten time more expensive $\mathrm{C}_{70}$ derivatives, the use of precious metals in electrodes, toxic high-boiling point solvents, the introduction of additives, the application of specific thermal or solvent annealing processes are so many factors that contribute to increase the cost and environmental impact of the chemistry and technology of OPV. Furthermore, most of the cells reported so far, including some record devices, have active area of a few $\mathrm{mm}^{2}$. Taking into account the decrease of PCE with size extension, ${ }^{[91]}$ the disparity of the architectures, geometries and size of the devices is a source of confusion. First because it gives poor indication about the efficiency of OPV panels of realistic dimensions and hence of the actual cost of OPV electricity, and second because it makes very difficult comparison of different molecules when not evaluated in the same device. Table 1 which presents some of the best results reported for OPV cells based on molecular donors of low molecular weight gives an illustration of this problem. In this regard, the adoption of a standard active area for evaluation of OPV materials as recently suggested by Krebs would certainly represent a progress. ${ }^{[111]}$

Although the targets of OPV have been a matter of debate, it seems now clear that niche markets such as power supplies for cell-phones or laptops cannot justify the research effort and investment needed to develop a viable OPV technology. In fact, the industrial future of OPV lies in solar modules for buildings or vehicles which implies that a confrontation with silicon technology will be difficult to dodge. In such a context a continuation of the race toward higher PCE at any price without considering lateral factors might well lead to a dead-end. The only chance for OPV to compete or co-exist with silicon technology is to demonstrate decisive advantages in terms of cost and environmental impact, namely dividing by factor of ten the price of the PV electricity while still presenting decent PCE and lifetime. This would imply drastic reduction of all input and output costs of OPV fabrication,

Table 1. Photovoltaic parameters of OPV cells based on representative small molecular donors with molecular weight inferior to 500 .

\begin{tabular}{|c|c|c|c|c|c|c|c|c|c|c|c|c|}
\hline \multirow[t]{2}{*}{ Donor } & \multirow[t]{2}{*}{ MW } & \multirow{2}{*}{$\begin{array}{l}\lambda_{\max } \\
{[\mathrm{nm}]}\end{array}$} & \multirow{2}{*}{$\begin{array}{c}\text { Area } \\
{\left[\mathrm{mm}^{2}\right]}\end{array}$} & \multirow[t]{2}{*}{ A } & \multicolumn{2}{|c|}{ Buffer layer } & \multirow[t]{2}{*}{$\mathrm{CM}$} & \multirow{2}{*}{$\begin{array}{l}V_{\text {oc }} \\
{[\mathrm{V}]}\end{array}$} & \multirow{2}{*}{$\begin{array}{c}J_{\mathrm{sc}} \\
{\left[\mathrm{mA} \mathrm{cm}^{-2}\right]}\end{array}$} & \multirow{2}{*}{$\begin{array}{l}F F \\
{[\%]}\end{array}$} & \multirow{2}{*}{$\begin{array}{l}P C E \\
{[\%]}\end{array}$} & \multirow[t]{2}{*}{ Ref. } \\
\hline & & & & & An & Cat & & & & & & \\
\hline & 494 & & 4.00 & $C_{60}$ & $P$ & yes & $\mathrm{Ag}-\mathrm{Mg}$ & 0.68 & 5.60 & 39 & 1.50 & {$[46]$} \\
\hline & 482 & 518 & 2.96 & $\mathrm{C}_{60}$ & IC & & ITO & 0.97 & 2.90 & 42 & 1.20 & [57] \\
\hline & 440 & 534 & 28.0 & $\mathrm{C}_{60}$ & $P$ & no & $\mathrm{Al}$ & 0.83 & 5.40 & 45 & 2.02 & [62] \\
\hline & 278 & & 13.0 & $\mathrm{C}_{60}$ & $P$ & yes & $\mathrm{Al}$ & 0.36 & 8.20 & 50 & 1.50 & [68] \\
\hline & 228 & & 12.0 & $\mathrm{C}_{60}$ & $P$ & yes & $\mathrm{Al}$ & 0.58 & 7.00 & 57 & 2.30 & [70] \\
\hline & 387 & 595 & 7.85 & $C_{70}$ & $P$ & yes & $\mathrm{Ba}-\mathrm{Ag}$ & 1.00 & 10.20 & 44 & 4.50 & [97] \\
\hline & 403 & & 8.00 & & $M$ & yes & $\mathrm{Ag}$ & 0.96 & 12.60 & 47 & 6.10 & [96] \\
\hline & 403 & 501 & 28.0 & $C_{60}$ & $P$ & no & $\mathrm{Al}$ & 0.99 & 6.24 & 64 & 4.00 & [108] \\
\hline & 483 & 570 & 2.50 & $C_{70}$ & $M$ & yes & $\mathrm{Ag}$ & 0.93 & 13.48 & 53 & 6.80 & [101] \\
\hline & 327 & 473 & 28.0 & $\mathrm{C}_{60}$ & $P$ & no & Al & 0.65 & 6.80 & 39 & 1.92 & [109] \\
\hline
\end{tabular}

A: acceptor, Buffer layer An: Anodic, P: PEDOT:PSS, M: $\mathrm{MoO}_{3}$, Cat: Cathodic, CM: Cathode material, IC: inverted cell 
electrodes, active materials, labour, energy, chemical wastes and recycling etc. ${ }^{[112]}$

In this article various classes of molecular structures that can represent possible starting points for the development of simple and cost-effective materials have been discussed. Although interesting results have already been obtained with molecules that combine efficiency and simplicity, considerable further effort is needed to develop new classes of materials that associate efficiency, low cost, clean and scalable syntheses and purification. This is clearly a difficult challenge which requires intensification of basic research on the various aspects of the chemistry of conjugated systems from cleaner and more efficient synthetic methods to deeper analyses of structure-properties relationships at the various relevant levels: molecular, intermolecular, and device. Although the success is not warranted, it seems evident that research effort focused on simplification will anyway produce valuable results for the progress of the science of $\pi$-conjugated systems, even if not necessarily in the areas where they were initially expected.

"Simplicity is the ultimate form of sophistication", Leonardo da Vinci

Received: December 6, 2013 Revised: January 25, 2014 Published online: March 31, 2014

[1] A. K. Gosh, D. L. Morel, T. Feng, R. F. Shaw, C. A. Rowe Jr, J. Appl. Phys. 1974, 45, 230.

[2] R. O. Loutfy, E. R. Menzel, J. Am. Chem. Soc. 1980, 102, 4967.

[3] V. Y. Merritt, H. J. Hovel, Appl. Phys. Lett. 1976, 29, 414.

[4] D. L. Morel, A. K. Gosh, T. Feng, E. L. Stgryn, P. E. Purwin, R. F. Shaw, C. Fishman, Appl. Phys. Lett. 1978, 22, 495.

[5] G. A. Chamberlain, P. J. Cooney, S. Dennison, Nature 1981, 289, 5793.

[6] G. A. Chamberlain, J. Appl. Phys. 1982, 53, 6262.

[7] G. A. Chamberlain, Solar Cells 1983, 8, 47-83.

[8] C. W. Tang, Appl. Phys. Lett. 1986, 48, 183.

[9] D. Wöhrle, D. Meissner, Adv. Mater. 1991, 3, 129

[10] P. Peumans, A. Yakimov, S. R. Forrest, J. Appl. Phys. 2003, 93, 3693

[11] Handbook of Conductive Polymers, $7^{\text {st }}$ Edition, Ed: T. Skotheim, Marcel Dekker, 1986; $2^{\text {nd }}$ Edition, Ed. J. Reynolds, T. Skotheim, R. Elsenbaumer, Marcel Dekker, 1997; Inc.; $3^{\text {rd }}$ Edition, Ed, T. Skotheim, J. Reynolds, CRC Press 2007

[12] J. H. Burroughes, D. D. C. Bradley, A. R. Brown, R. N. Marks, R. H. Friend, P. L. Burns, A. B. Holmes, Nature 1990, 347, 539.

[13] S. Glenis, G. Horowitz, G. Tourillon, F. Garnier, Thin Solid Films 1984, 111, 93.

[14] N. S. Sariciftici, L. Smilowitz, A. J. Heeger, Science 1992, 258, 1474.

[15] G. Yu, J. Gao, J. C. Hummelen, F. Wudl, A. J. Heeger, Science 1995, 270, 1789.

[16] J. J. M. Halls, C. A. Walsh, N. C. Greenham, E. A. Marseglia, R. H. Friend, S. C. Moratti, A. B. Holmes, Nature 1995, 376, 498.

[17] S. Shaheen, C. J. Brabec, N. S. Sariciftci, F. Padinger, T. Fromherz, J. C. Hummelen, Appl. Phys. Lett. 2001, 78, 841.

[18] P. Schilinsky, C. Waldauf, C. J. Brabec, Appl. Phys. Lett. 2002, 81, 3885.

[19] a) M. Reyes-Reyes, K. Kim, D. L. Carroll, Appl. Phys. Lett. 2005, 87, 083506; b) G. Li, V. Schrotriya, J. Huang, Y. Yao, T. Moriarty, K. Emery, Y. Yang, Nat. Mater. 2005, 864; c) W. Ma, C. Yang, X. Gong, K. Lee, A. J. Heeger, Adv. Funct. Mater. 2005, 15, 1617.
[20] T. D. Minh, L. Hirsh, G. Wantz, Adv. Mater. 2011, 23, 3597.

[21] J. Roncali, Chem. Rev. 1997, 97, 173.

[22] a) A. Dhanabalan, J. K. J. van Duren, P. A. Van Hal, J. L. J. van Dongen, R. A. J. Janssen, Adv. Funct. Mater. 2001, 11, 255; b) M. Svensson, F. Zhang, S. C. Veenstra, W. J. H. Verhees, J. C. Hummelen, J. M. Kroon, O. Inganäs, M. R. Andersson, Adv. Mater. 2003, 15, 988; c) C. Winder, N. S. Sariciftci, J. Mater. Chem. 2004, 14, 1077.

[23] Y-J. Cheng, S. H. Yang, C.-S. Hsu, Chem. Rev. 2009, 109, 5868.

[24] a) E. Wang, L. Wang, L. Lan, C. Luo, W. Zhuang, J. Peng, Y. Cao, Appl. Phys. Lett. 2008, 92, 033307; b) Y. Liang, L. Yu, Acc. Chem. Res. 2010, 43, 1227.

[25] Z. He, C. Zhong, S. Su, M. Xu, H. Wu, Y. Cao, Nature Photonics 2012, 6, 591 .

[26] C. Cabanetos, A. El Labban, J. A. Barteld, J. D. Douglas, W. M. Mateker, J. M. J. Fréchet, M. D. McGhee, P. M. Beaujuge, J. Am. Chem. Soc. 2013, 135, 4656.

[27] J. Roncali, P. Frère, P. Blanchard, R. de Bettignies, M. Turbiez, S. Roquet, P. Leriche, Y. Nicolas, Thin Solid Films 2006, 511, 567.

[28] Reviews: a) M. T. Lloyd, J. M. Anthony, G. C. Malliaras, Materials Today 2007, 10, 34; b) J. Roncali, Acc. Chem. Res. 2009. 42, 1719; c) Y. Li, Q. Guo, Z. Li, J. Pei, W. Tian, Energy Q Environmental Science 2010, 3, 1427; d) B. Walker, C. Kim, T.-Q. Nguyen, Chem. Mater. 2011, 23, 470; e) A. Mishra, P. Bäuerle, Angew. Chem. Int. Ed. 2012, 51, 2020; f) Y. Lin, Y. Li, X. Zhan, Chem. Soc Rev. 2012, $41,4245$.

[29] a) S. Roquet, R. Bettignies, P. Leriche, J. Roncali, J. Mater. Chem. 2006, 16, 3040; b) X. Sun, Y. Zhou, W. Wu, Y. Liu, W. Tian, G. Yu, W. Qiu, S. Chen, D. Zhu, J. Phys. Chem. B. 2006, 110, 7702; c) S. Karpe, A. Cravino, P. Frère, M. Allain, G. Mabon, J. Roncali, Adv. Funct. Mater. 2007, 17, 1163.

[30] S. Roquet, A. Cravino, P. Leriche, A. Alévêque, P. Frère, J. Roncali, J. Am. Chem. Soc. 2006, 128, 3459; b) H. Shang, H. Fan, Y. Liu, W. Hu, Y. Li, X. Zhan, Adv. Mater. 2011, 23, 1554.

[31] A. B. Tamayo, B. Walker, T.-Q. Nguyen, J. Phys. Chem. C. 2008, 112, 11545; b) B. Walker, A. B. Tamayo, X.-D. Dang, P. Zalar, J. H. Seo, A. Garcia, M. Tantiwiwat, T.-Q. Nguyen, Adv. Funct. Mater. 2009, 19, 3063.

[32] T. Rousseau, A. Cravino, T. Bura, G. Ulrich, R. Ziessel, J. Roncali, Chem. Commun. 2009, 1673; b) T. Rousseau, A. Cravino, E. Ripaud, P. Leriche, S. Rihn, A. De Nicola, R. Ziessel, J. Roncali, Chem. Commun. 2010, 5082.

[33] J. Mei, K. R. Graham, R. Stalder, J. R. Reynolds, Org. Lett. 2010, 12, 660.

[34] L. L. Xue, J. T. He, X. Gu, Z. F. Yang, B. Xu, W. J. Tian, J. Phys. Chem. C 2009, 113, 12911

[35] a) Y. Sun, G. C. Welch, W. L. Leong, C. J. Takacs, G. C. Bazan, A. J. Heeger, Nat. Mater. 2011, 11, 44; b) J. E. Coughlin, Z. B. Henson, G. C. Welch, G. Bazan, Acc. Chem. Res. 2014, 47, 257

[36] a) J. Zhou, Y. Zuo, X. Wan, G. Long, Q. Zhang, W. Ni, Y. Liu, Z. Li, G. He, C. Li, B. Kan, M. Li, Y. Chen, J. Am. Chem. Soc. 2013, 135, 8484; b) Y. Chen, X. Wan, G. Long, Acc. Chem. Res. 2013, 46, 2645.

[37] S. Shen, P. Jiang, C. He, J. Zhang, P. Shen, Y. Zhang, Y. Yi, Z. Zhang, Z. Li, Y. Li, Chem. Mater. 2013, 25, 2274.

[38] Y.-H. Chen, L.-Y. Lin, C.-W. Lu, F. Lin, Z.-Y. Huang, H.-W. Lin, P.-H. Wang, Y.-H. Liu, K.-T. Wong, J. Wen, D. J. Miller, S. B. Darling, J. Am. Chem. Soc. 2012, 134, 13616.

[39] R. Fitzner, E. Mena-Osteritz, A. Mishra, G. Schulz, E. Reinold, M. Weil, C. Körner, H. Ziehlke, C. Elschner, K. Leo, M. Riede, M. Pfeiffer, C. Ulrich, P. Bäuerle, J. Am. Chem. Soc. 2012, 134, 11064.

[40] J. You, C.-C Chen, Z. Hong, K. Yoshimura, K. Ohya, R. Xu, S. Ye, J. Gao, G. Li, Y. Yang, Adv. Mater. 2013, 25, 3973.

[41] D. J. Burke, D. J. Lipomi, Energy Environ. Sci. 2013, 6, 2053. 
[42] T. P. Osedach, T. L. Andrew, V. Bulovic, Energy Environ. Sci. 2013, 6,711 .

[43] U. Schoeler, K. H. Tews, H. Kuhn, J. Chem. Phys. 1974, 61, 5009.

[44] N. Noma, T. Tsuzuki, Y. Shirota, Adv. Mater. 1995, 7, 647.

[45] C. Videlot, A. El Kassmi, D. Fichou, Sol. Energy Mater. Sol. Cells 2000, 63, 69 .

[46] J. Sakai, T. Taima, K. Saito, Organic Electronics 2008, 9, 582.

[47] G. Barbarella, O. Pudova, C. Arbizzani, M. Mastragostino, A. Bongini, J. Org. Chem. 1998, 63, 1742.

[48] N. Camaioini, G. Ridolfi, V. Fattori, L. Favaretto, G. Barbarella, Appl. Phys. Lett 2004, 84, 1901

[49] a) P. Liu, Q. Li, M. Huang, W. Pan, Appl. Phys. Lett. 2006, 89, 213501; b) L. Guan, J. Wang, J. Huang, C. Jiang, M. La, P. Liu, W. Deng, Synthetic Communications 2011, 41, 3662.

[50] A. Yassar, C. Videlot, A. Jaafari, Solar Energy Materials \& Solar cells 2006, 90, 916

[51] K. Schulze, C. Uhrich, R. Schüppel, K. Leo, M. Pfeiffer, E. Brier, E. Reinold, P. Bäuerle, Adv. Mater. 2006, 18, 2872.

[52] K. Schulze, M. Riede, E. Brier, E. Reinold, P. Bäuerle, K. Leo, J. Appl. Phys. 2008, 104, 074511.

[53] R. Fitzner, C. Elshner, M. Weil, C. Ulrich, C. Körner, M. Riede, K. Leo, M. Pfeiffer, E. Reinold, E. Mena-Osteritz, P. Bäuerle, Adv. Mater. 2012, 24, 675.

[54] D. Wynands, B. Männing, M. Riede, K. Leo, E. Brier, E. Reinold, P. Bäuerle, J. Appl. Phys. 2009, 106, 054509.

[55] D. Wynands, M. Levichkova, M. Riede, M. Pfeiffer, P. Bäuerle, R. Rentenberger, P. Denner, K. Leo, J. Appl. Phys. 2010, 107, 014517.

[56] D. Wynands, M. Levichkova, K. Leo, C. Uhrich, G. Schwartz, D. Hildebrandt, M. Pfeiffer, M. Riede, Appl. Phys. Lett. 2010, 97, 073503.

[57] R. Fitzner, E. Reinold, A. Mishra, E. Mena-Osteritz, H. Ziehlke, C. Körner, K. Leo, M. Riede, M. Weil, O. Tsaryova, A. Weiss, C. Uhrich, M. Pfeiffer, P. Bäuerle, Adv. Funct. Mater. 2011, 21, 897.

[58] S. Steinberger, A. Mishra, E. Reinold, C. M. Müller, C. Uhrich, M. Pfeiffer, P. Bäuerle, Org. Lett. 2011, 13, 90.

[59] S. Steinberger, A. Mishra, E. Reinold, J. Levichkov, C. Uhrich, M. Pfeiffer, P. Bäuerle, Chem. Commun 2011, 47, 1982.

[60] J. Roncali, P. Blanchard, P. Frère, J. Mater. Chem. 2005, 15, 1589.

[61] A. Cravino, S. Roquet, O. Alévêque, P. Frère, P. Leriche, J. Roncali, Chem. Mater. 2006, 18, 2584.

[62] D. Demeter, T. Rousseau, J. Roncali, RSC Advances 2013, 3, 704.

[63] E. Ripaud, T. Rousseau, P. Leriche, J. Roncali, Adv. Energy Mater. 2011, 1, 540.

[64] A. Mishra, C.-Q. Ma, P. Bäuerle, Chem. Rev. 2009, 109, 1141.

[65] a) H. Kallman, M. Pope, J. Chem. Phys. 1959, 30, 585; b) W. Moore, M. Silver, J. Chem. Phys. 1960, 33, 1671.

[66] a) N. Geacintov, M. Pope, H. Kallman, J. Chem. Phys. 1966, 45, 2639; b) A. K. Gosh, T. Teng, J. Appl. Phys. 1973, 44, 2781.

[67] R. Signerski, G. Jarosz, J. Godlewski, Synth. Met. 1998, 94, 135.

[68] S. Yoo, B. Domercq, B. Kippelen, Appl. Phys. Lett. 2004, 85, 5427.

[69] L. C. Palilis, P. A. Lane, G. P. Kushto, B. Purushomatan, J. E. Anthony, Z. H. Kafafi, Organic Electronics 2008, 9, 747.

[70] C. W. Chu, Y. Chao, V. Shrotriya, Y. Yang, Appl. Phys. Lett. 2005, 86, 243506.

[71] A. K. Pandey, K. N.N Unni, J.-M. Nunzi, Thin Solid Films. 2006, 511, 529.

[72] A. K. Pandey, J. M. Nunzi, Adv. Mater. 2007, 19, 3613.

[73] A. A. Gorodedetsky, M. Cox, N. J. Tremblay, I. Kymissis, C. Nuckolls, Chem. Mater. 2009, 21, 4090.

[74] M. T. Lloyd, A. C. Mayer, A. S. Tayi, A. M. Bowen, T. G. Kasqen, D. J. Herman, D. A. Mourey, J. E. Anthony, G. G. Malliaras, Organic Electronics 2006, 7, 243.

[75] M. T. Lloyd, A. C. Mayer, S. Subramanain, D. A. Mourey, D. J. Herman, A. V. Bapat, J. E. Anthony, G. G. Malliaras, J. Am. Chem. Soc. 2007, 129, 9144.
[76] K. N. Winzenberg, P. Kemppinen, G. Fanchini, M. Brow, G. E. Collis, C. M. Forsyth, K. Hegedus, Th. B. Singh, S. E. Watkins, Chem. Mater. 2009, 21, 5701.

[77] a) K.-Y. Law, Chem. Rev. 1993, 93, 449; b) S. Sreejith, P. Carol, P. Chithra, A. J. Ajayaghosh, J. Mater. Chem. 2008, 18, 264.

[78] V. Y. Merritt, H. J. Hovel, Appl. Phys. Lett. 1976, 29, 414

[79] M. Iwamoto, S. I. Shidoh, Jpn. J. Appl. Phys. 1990, 29, 2031.

[80] E. E. Havinga, W. ten Hoeve, H. Wynberg, Synth. Met. 1993, 55-57, 299.

[81] S. Wang, E. I. Mayo, M. D. Perez, L. Griffe, G. Wie, P. I. Djurovich, S. R. Forrest, M. E. Thompson, Appl. Phys. Lett. 2009, 94, 233304.

[82] G. Wei, S. Wang, K. Renshaw, M. E. Thompson, S. R. Forrest, ACS Nano 2010, 4, 1927.

[83] G. Wei, S. Wang, K. Sun, M. E. Thompson, S. R. Forrest, Adv. Energy Mater. 2011, 1, 184

[84] G. Chen, H. Sasabe, Z. Wang, X. Wang, Z. Hong, J. Kido, Y. Yang, Phys. Chem. Chem. Phys. 2012, 14, 14661.

[85] B. Fan, Y. Maniglio, M. Simeunovic, S. Kuster, T. Geiger, R. Nany, F. Nüesh, Int. J. Photoenergy 2009, 581068.

[86] U. Mayerhöffer, K. Deing, K. Gruss, H. Branschweig, K. Meerholz, F. Würthner, Angew. Chem. Int. Ed. 2009, 48, 8776.

[87] D. Yang, Q. Yang, L. Yang, Q. Luo, Y. Huang, Z. Lu, S. Zhao, Chem. Commun. 2013, 49, 10465.

[88] A. Cravino, P. Leriche, O. Alévêque, S. Roquet, J. Roncali, Adv. Mater. 2006, 18, 3033

[89] G. Wei, X. Xiao, J. D. Zimmerman, K. Sun, V. V. Diev, M. E. Thompson, S. R. Forrest, Nano Lett. 2011, 11, 4261.

[90] a) D. Bagnis, L. Beverina, H. Huang, F. Silvestri, Y. Yao, H. Yan, G. A. Pagani, T. J. Marks, A. Facchetti, J. Am. Chem. Soc. 2010, 132 4074; b) L. Beverina, M. Dress, A. Fachetti, M. Salamone, R. Ruffo, G. A. Pagani, Eur. J. Org. Chem. 2011, 5555.

[91] W.-I. Jeong, J. Lee, S.-Y. Park, J.-W. Kang, J.-J. Kim, Adv. Funct. Mater. 2011, 21, 343.

[92] A. K. Ghosh, T. Feng, J. Appl. Phys. 1978, 49, 5982.

[93] M. M. Kronenberg, M. Deppish, F. Würthner, H. W. A. Ledemann, K. Deing, K. Meerholz, Chem. Commun. 2008, 6489.

[94] V. Steinman, N. M. Kronenberg, M. R. Lenze, S. M. Graf D. Hertel, H. Bürckstümmer, F. Würthner, K. Meerholz, Appl. Phys. Lett. 2011, 99, 193306.

[95] H. Bürckstümmer, N. M. Kronenberg, M. Gsänger, M. Stolte, K. Meerholz, F. Würthner, J. Mater. Chem. 2010, 20, 240.

[96] V. Steinmann, N. M. Kronenberg, M. R. Lenze, S. M. Graf D. Hertel, K. Meerholz, H. Bürckstümmer, E. V. Tulyakova, F. Würthner, Adv. Energy Mater. 2011, 1, 888.

[97] H. Bürckstümmer, E. V. Tulyakova, M. Deppish, M. R. Lenze, N. M. Kronenberg, M. Gsänger, M. Stolte, K. Meerholz, F. Würthner, Angew. Chem. Int. Ed. 2011, 50, 11628

[98] H.-W. Lin, L.-Y. Lin, Y.-H. Chen, C.-W. Chen, Y.-T. Lin, S.-W. Chiu, K.-T. Wong, Chem. Commun. 2011, 47, 7872.

[99] L.-Y. Lin, Y.-H. Chen, Z.-Y. Huang, H.-W. Lin, S.-H. Chou, F. Lin, C.-W. Chen, Y-H. Liu, K-T. Wong, J. Am. Chem. Soc. 2011, 133, 15822.

[100] S-W. Chui, L-Y. Lin, H-W. Lin, Y-H. Chen, Z-Y Hunag, Y-T. Lin, F. Lin, Y-H. Liu, K-T. Wong, Chem. Commun. 2012, 48, 1857.

[101] Y.-H. Chen, L.-Y. Lin, C.-W. Lu, F. Lin, Z.-Y. Huang, H.-W. Lin, P.-H. Wang, Y.-H. Liu, K.-T. Wong, J. Wen, D. J. Miller, S. B. Darling, J. Am. Chem. Soc. 2012, 134, 13616.

[102] M. J. Cho, J. Seo, H. S. Oh, H. Jee, W. J. Kim, K. H. Kim, M. H. Hoang, D. H. Choi, P. N. Prasad, Solar Energy Materials Q Solar Cells 2012, 98, 71 .

[103] J. C. Bernède, L. Cattin, M. Makha, P. Leriche, J. Roncali, V. Froger, M. Morsli, M. Addou, Solar Energy Mater. 2013, 110, 107.

[104] A. Leliège, C.-H. Le Régent, M. Allain, P. Blanchard, J. Roncali, Chem Commun. 2012, 48, 8907.

[105] A. Leliège, D. Demeter, V. Jeux, T. Rousseau, P. Leriche, P. Blanchard, J. Roncali, Chem Eur. J. 2013, 19, 9948. 
[106] D. Demeter, V. Jeux, P. Leriche, P. Blanchard, Y. Olivier, J. Cornil, R. Po, J. Roncali, Adv. Funct. Mater. 2013, 23, 4854.

[107] a) H. Brisset, P. Blanchard, B. Illien, A. Riou, J. Roncali, Chem. Commun. 1997, 569; b) J. M. Raimundo, P. Blanchard, N. GallegoPlanas, N. Mercier, I. Ledoux-Rak, R. Hierle, J. Roncali, J. Org. Chem. 2002, 67, 205

[108] J. W Choi, C. H. Kim, J. Pison, A. Oyedele, H. Derbal-Habak, D. Tondelier, A. Leliège, E. Kirchner, P. Blanchard, J. Roncali, B. Geffroy, RSC Advances 2014, 4, 5236.
[109] V. Jeux, D. Demeter, P. Leriche, J. Roncali, RSC Advances 2013, 3, 5811.

[110] R. de Bettignies, Y. Nicolas, P. Blanchard, E. Levillain, J. M. Nunzi, J. Roncali, Adv. Mater. 2003, 15, 1939.

[111] M. Jørgensen, J. E. Carlé, R. R. Søndergaard, M. Lauritzen, N. A. Dagnae-Hansen, S. L. Byskov, T. R. Andersen, T. T. LarsenOlsen, A. P. L. Böttiger, B. Andreasen, L. Fu, L. Zhuo, Y. Liu, E. Bundgaard, X. Zhan, H. Chen, F. Krebs, Solar Energy Mater.eT Solar Cells 2013, 119, 84.

[112] F. Krebs, M. Jørgensen, Solar Energy Mater. ๔ Solar Cells 2013, 119, 73. 